NBER WORKING PAPER SERIES

\title{
THE HISTORICAL STATE, LOCAL COLLECTIVE ACTION, AND ECONOMIC DEVELOPMENT IN VIETNAM
}

\author{
Melissa Dell \\ Nathaniel Lane \\ Pablo Querubin \\ Working Paper 23208 \\ http://www.nber.org/papers/w23208 \\ NATIONAL BUREAU OF ECONOMIC RESEARCH \\ 1050 Massachusetts Avenue \\ Cambridge, MA 02138 \\ March 2017
}

We thank Minh Trinh, Nhung Le, Minh Tuan Nguyen, Thao Ngo, and Huyen Cao for providing excellent research assistance. We are also grateful to seminar participants at Berkeley, the Canadian Institute for Advanced Research, Central European University, Columbia University, CUNY, Duke Economics, Duke Political Science, Harvard, IIES, LACEA, LSE, MIT, Munich, NYU, Oxford, Queen Mary, UC-Santa Barbara, Universidad de Piura, University of Illinois Urbana-Champaign, Warwick, World Bank and Yale for their helpful comments and suggestions. Support used to fund this project was received from the Weatherhead Center for International Affairs (Harvard), the Milton Fund (Harvard), and the Canadian Institute for Advanced Research. The views expressed herein are those of the authors and do not necessarily reflect the views of the National Bureau of Economic Research.

NBER working papers are circulated for discussion and comment purposes. They have not been peer-reviewed or been subject to the review by the NBER Board of Directors that accompanies official NBER publications.

(C) 2017 by Melissa Dell, Nathaniel Lane, and Pablo Querubin. All rights reserved. Short sections of text, not to exceed two paragraphs, may be quoted without explicit permission provided that full credit, including $\odot$ notice, is given to the source. 
The Historical State, Local Collective Action, and Economic Development in Vietnam Melissa Dell, Nathaniel Lane, and Pablo Querubin

NBER Working Paper No. 23208

March 2017

JEL No. N15,O43

\begin{abstract}
$\underline{\text { ABSTRACT }}$
This study examines how the historical state conditions long-run development, using Vietnam as a laboratory. Northern Vietnam (Dai Viet) was ruled by a strong centralized state in which the village was the fundamental administrative unit. Southern Vietnam was a peripheral tributary of the Khmer (Cambodian) Empire, which followed a patron-client model with weaker, more personalized power relations and no village intermediation. Using a regression discontinuity design across the Dai Viet-Khmer boundary, the study shows that areas historically under a strong state have higher living standards today and better economic outcomes over the past 150 years. Rich historical data document that in villages with a strong historical state, citizens have been better able to organize for public goods and redistribution through civil society and local government. This suggests that the strong historical state crowded in village-level collective action and that these norms persisted long after the original state disappeared.
\end{abstract}

Melissa Dell

Department of Economics

Harvard University

Littauer M-24

Cambridge, MA 02138

and NBER

melissadell@fas.harvard.edu

Nathaniel Lane

Institute for International Economic Studies

Stockholm University

Attn: Nathaniel Lane

SE-106 91 Stockholm

Sweden

nathaniel.lane@iies.su.se
Pablo Querubin

New York University

Department of Politics

19 W 4th Street, Room 208

New York, NY 10012

pablo.querubin@nyu.edu

A Online appendix is available at http://www.nber.org/data-appendix/w23208 


\section{Introduction}

The past century has witnessed a large-scale divergence in economic prosperity within the developing world. In particular, initially poor economies in Northeast Asia - such as Japan, Taiwan, and South Korea - have developed much more rapidly on average than economies in Southeast Asia - such as the Philippines and Cambodia. One central difference between these regions is the nature of the historical state, but it is challenging to deduce what role this played in the divergence since many factors differ. Progress can be made by focusing on a single country - Vietnam - that lies at the intersection of Northeast and Southeast Asia. This study uses a regression discontinuity design to compare nearby Vietnamese villages that belonged to different historical states, employing rich historical data to elucidate channels of persistence. We hypothesize that the historical state crowded in local collective action, and that these norms persisted, influencing civic engagement, public goods provision, and economic development long after the historical state had disappeared.

Northeast Asia historically had central states with well-developed tax systems, bureaucracies, and legal codes. Importantly, the village was the fundamental administrative unit. The central state set quotas for tax and military conscript contributions at the village level and often designed legal codes with an eye towards preventing local strongmen from becoming sufficiently powerful to challenge the national government. These pre-modern states did not, however, have the capability to micro-manage local administration, and villages had considerable autonomy in how to implement policies. Villagers had to work together to provide local public goods and meet the village-level tax and military quotas. In contrast, Southeast Asian states followed a more decentralized patron-client model. Power relations were personalized, with peasants paying tribute and receiving protection from landowning patrons, who in turn had their own network of relations with higher level patrons. The village was not a central unit of administrative organization.

The northern Vietnamese state of Dai Viet was governed by China during the first millennium CE, and it maintained many features of the Chinese state following independence. During the 14th through 19th centuries, Dai Viet gradually expanded southward, establishing village governance norms in what is now central Vietnam (see Figure 1). Most of this expansion came via conquering the territory of Champa, a relatively weak state that historically occupied central Vietnam. Local affairs in Dai Viet villages were coordinated by village councils elected by popular male suffrage. ${ }^{1}$ In contrast, the southernmost part of modern Vietnam was historically a peripheral tributary of the Cambodian state of Khmer. Khmer had a weak control of its periphery, and patron-client relationships, not villages, were the

\footnotetext{
${ }^{1}$ Evidence on the impacts of elections in pre-modern states is limited, but Martinez-Bravo et al. (2012) show that in recent years the introduction of local elections in China significantly increased public goods provision.
} 
central feature of local administration. While some Vietnamese settlers had entered the region earlier, the Khmer areas of modern Vietnam were not administratively organized along Vietnamese lines until 1833, leaving little time for Vietnamese institutions to take root before French colonial occupation in 1859. Colonial rule reinforced the pre-existing differences, with the French exploiting village structures where they were well-established and relying on more direct means of control where they were not.

Table 1 summarizes key characteristics of the Khmer and Vietnamese states. Section 2 discusses the many similarities between Dai Viet and other Northeast Asian states, and between Khmer and other Southeast Asian states. While care must be taken with external validity, these similarities suggest that the Vietnamese context is informative about differences between Northeast and Southeast Asia more generally.

This study examines the boundary between Khmer and Dai Viet, which was established in 1698 and is denoted by a thick line in Figure 1. Villages on one side belonged to Dai Viet for over 150 years prior to French colonization, whereas villages on the other were organized along Vietnamese administrative lines only a few decades prior to the arrival of the French. Section 2 documents that this boundary was meaningful and was the result of idiosyncratic circumstances that prevented Dai Viet from conquering further Khmer territory until they resolved an internal civil war. Geographic characteristics are similar on either side, suggesting that villages just to the Khmer side are a reasonable counterfactual for those just to the Dai Viet side. We also examine the other boundaries of Dai Viet's expansion but do not expect major long-run effects, since villages along them were all governed by Dai Viet for centuries prior to French colonization.

Using a regression discontinuity design to compare nearby villages on either side of the Dai Viet-Khmer boundary, we find that household consumption in Dai Viet villages is around one third higher today. Results are highly robust to the selection of bandwidth and RD functional form. Ho Chi Minh City, the administrative center of Dai Viet's 1698 expansion, is in our study area, and the estimates change little when it - and the entire surrounding region - is dropped. They also change little when all provincial capitals are dropped, or when we limit to villages along segments of the boundary not formed or only formed by rivers. Moreover, the estimates are similar when we extend the sample to all of South Vietnam, rather than focusing on the boundary. We document that economic impacts also obtain historically, using data from the French colonial period collected between 1878 and 1926, household income data from the 1970s, and a variety of other historical economic indicators.

After considering contemporary living standards, we examine channels of persistence. While as always a number of mechanisms could be relevant, the historical and empirical evidence suggests that local collective action - through civil society and local government - is an important channel, and one that is interesting in its own right. This would often 
be unobserved, particularly historically, but Vietnam offers unusually rich historical data that allow us to examine it. Detailed information on civil society and local government are available for nearly all 18,000 South Vietnamese hamlets for the period between 1969 and 1973, and public opinion surveys were also collected for a random sample of hamlets.

Citizens in Dai Viet villages historically had to work together to meet their village's obligations to the central state, provide public goods, and elect their leaders, and these patterns persisted long after the dissolution of the Dai Viet central state. Citizens in villages with a historically strong state were nearly twice as likely between 1969 and 1973 to participate in local civic organizations. They were also more likely to organize and participate in self-development projects and local self-defense forces, to attend local government meetings, and to have civic organizations that redistributed to needy households. Today, though data on civil society are quite limited, available information shows that households in Dai Viet villages are more likely to donate to charitable organizations. These results - and the other results on mechanisms - survive using latent class analysis to address multiple hypothesis testing and are robust to the specification tests outlined above, including dropping Ho Chi Minh City. They are also robust to controlling for village size. Barriers to migration between villages in Vietnam are high, which may help explain why local social capital has been so persistent, as argued in Besley (1995).

A 1967 constitutional reform granted villages expansive budgetary powers and public goods provision responsibilities, with citizens electing village heads and councils. This makes 1969 to 1973 a particularly illuminating time to examine the historical state's long-run impacts on local governance. Dai Viet villages were more likely to collect taxes and the village head was more likely to actually reside in the village. They were also more likely to have all the positions filled on the village committee, which provides public goods. Importantly, Dai Viet villages provided better access to basic health care, education, and law enforcement. Citizens in Dai Viet villages reported that the local government was more responsive to their needs and that local officials were more successful, and they had better knowledge of the village administrative structure. These results suggest that participatory governance reforms work best in places with a history of participatory village governance.

There are no effects on public goods provided by the provincial government and Dai Viet citizens had more negative views of the national government, indicating that effects are unlikely to be driven by higher levels of government or more positive attitudes towards government in general. More recently, we continue to observe effects on access to secondary schooling, and in Dai Viet areas, individuals have almost a year of additional schooling.

The literature finds that ethnic heterogeneity is an important determinant of collective action, but it does not appear to be a direct cause of the effects we find. ${ }^{2}$ While ethnic

\footnotetext{
${ }^{2}$ See Bazzi and Gudgeon (2016); Montalvo and Reynal-Querol (2005b,a); Alesina and La Ferrara (2005);
} 
composition may have differed historically, today there is almost no ethnic heterogeneity within villages. Nearly everyone identifies as Vietnamese, which was also true 50 years ago.

The study also examines plausible alternative mechanisms. Extensive evidence indicates that the effects are unlikely to be driven by differential impacts of the Vietnam War, with a variety of measures suggesting that conflict was similar across the boundary. Effects likewise do not appear to be driven by recent land inequality. Dai Viet households are less likely to be agricultural today, but within agriculture there is not a difference in average farm size. Moreover, while $97 \%$ of French-owned land was located in Khmer areas at the close of the colonial period, there were almost no French estates near the Dai Viet boundary.

However, a lower share of land is formally titled in Dai Viet villages today. This contrasts with conventional wisdom - based mostly on evidence from the West - which associates capable states with the protection of formal property rights and promotion of impersonal markets. Historically Dai Viet implemented certain formal institutions - a legal code, an impersonal tax system, a census registry, local elections, etc - whereas in Khmer areas personalistic ties dominated. However, Dai Viet also emphasized redistribution of property within the village, in order to prevent the emergence of local strongmen who could challenge the state. Accepted traditional norms of de facto property management by civil society networks and local governments plausibly play a more central role in ensuring property rights in Dai Viet villages than formal titles introduced relatively recently by the central government in Hanoi. This suggests a crowding out of formal institutions that is similar to the processes documented in Greif (1994) and Greif and Tabellini (2010).

The study contributes to our understanding of the relationship between civil society and the state. It is unclear from the existing literature whether we would expect the state and civil society to be complements or substitutes. On the one hand, scholars such as Gouldner (1980) and Fukuyama (1995) argue that in the presence of a weak state, civil society emerges to substitute the state by providing protection and social insurance, whereas a powerful state can repress or co-opt any organizations that threaten it. Acemoglu et al. (2014) show that powerful ruling families in Sierra Leone are able to co-opt civil society organizations. In contrast, Skocpol (1995) argues that strong states can directly promote civil initiatives through legal protection and public services, and the state's legitimacy also relies on citizen's active participation and trust in institutions. ${ }^{3}$ Padro i Miquel et al. (2015) document that Chinese villages with temples - a measure of social capital - experienced larger increases in public goods following the introduction of local elections. ${ }^{4}$ Sociologist Peter Evans (1995) hypothesizes that in Japan and South Korea, a capable state and an active civil society are

\footnotetext{
Alesina et al. (1999); Easterly and Levine (1997)

${ }^{3}$ See Lehning (1998), Hoover (2000) and Woolcock and Narayan (2000) for a review of the theory on the relationship between states and social capital.

${ }^{4}$ For more information on challenges for village governance in China see Qian (2012).
} 
complements that provided the engine for rapid economic growth. Our results suggest that when the state and civil society do compliment each other, long-run growth is more likely. Moreover, complementarities between the state and civil society are consistent with the broader hypothesis that complementarities between culture and institutions play a central role in generating persistence (see Alesina and Giuliano (2015) for a review).

The study also speaks to an important social science debate about the nature of village development. In his classic The Moral Economy of the Peasant, James Scott (1977) argues that the village is the key institution of pre-capitalist society, characterized by an adherence to social arrangements that insure villagers against subsistence crises. Similarly, Hayami (1980, p. 27) argues that the East Asian village acts as "a community which mobilizes collective actions to supply essential public goods." In contrast, other scholars view prisoners dilemmas, free rider problems, and other barriers to collective action - such as zero sum mentalities - as prohibitive, and hence argue that when development happens in rural areas, it is in spite of village social arrangements. ${ }^{5}$ Notably Samuel Popkin (1976) argues that organizing to supply public goods is precisely what villagers find very difficult, due to the limited abilities of peasants to generate village-wide insurance or welfare arrangements.

Interestingly, Scott conducted his fieldwork in central Vietnam, an area where villages had been ruled by Dai Viet for many centuries, whereas Popkin focused his work on Cochinchina, the French province in southern Vietnam where the former Khmer areas are located. Given our results, it is not surprising that they reached different conclusions. Some social scientists have examined qualitatively why village collective action differs, focusing largely on environmental determinism (Wade, 1994). This is essentially an efficient institutions view (Demsetz, 1967) - collective action will emerge where environmental factors lead the benefits to outweigh the costs. Our results provide quantitative evidence for another important explanation, the village's historical relationship with the central state.

Finally, the study contributes more broadly to the literatures on the persistence of social norms and institutions. The persistent impacts of the historical state, despite the upheavals that came with colonialism, the Vietnam War, and communism, are consistent with Roland (2012), who argues that culture in transition countries is more influenced by participation in historical empires for over 100 years than by the communist experience. ${ }^{6}$ Our results are also consistent with work by Michalopoulos and Papaioannou (2013) and Gennaioli and Rainer (2007) documenting that the organization of pre-colonial states affects long-run prosperity in Africa. By focusing on a single country with rich historical data, we are able to delve into mechanisms. More generally, this study relates to a large literature that highlights

\footnotetext{
${ }^{5}$ See for example Foster (1965).

${ }^{6}$ Our results are also plausibly consistent with Alesina and Fuchs-Schündeln (2007), who do find that communism affected social values but argue that these effects will be short lived.
} 
the relevance of historical states and historical institutions for long-run development and emphasizes the importance of persistent cultural traits. ${ }^{7}$ In particular, the results support the strand of the cultural economics literature that highlights social capital as a highly persistent determinant of economic divergence (Guiso et al., 2016; Putnam et al., 1994). This literature has focused extensively on Italy, whereas our results suggest that a social capital mechanism is also plausibly at play in explaining the relative prosperity of Northeast versus Southeast Asia, another central puzzle of modern economic growth. ${ }^{8}$

In the next section, we provide an overview of the historical context. Section 3 discusses identification and section 4 tests whether the historical state impacts contemporary living standards. Section 5 examines the mechanisms through which the impacts of the historical state persist. Finally, Section 6 offers concluding remarks.

\section{Historical Background}

\section{$2.1 \quad$ Historical Overview}

For most of the first millennium, the northern part of modern Vietnam was subject to Chinese overlordship. After gaining independence, the Vietnamese state of Dai Viet - whose original borders are shown by the northernmost polygon in Figure 1 - adopted the general political form of the Chinese state, over time modifying it to Vietnamese needs. The Vietnamese state maintained a competitive bureaucratic tradition, with an exam system used to select village bureaucrats. ${ }^{9}$ In 1461 the system was reformed so that village councils were elected by villagers through popular male suffrage, with national bureaucrats still selected through an exam system. ${ }^{10}$ These policies made Vietnamese local governance unusually participatory, by global standards and relative to the original Chinese model. ${ }^{11}$

Detailed legal codes institutionalized the relationship between the central state, which served as the impetus and enforcer for most policies, and local functionaries, who were responsible for implementation. ${ }^{12}$ The central state imposed tax and military recruitment quotas on the village, leaving the village authority to allocate tax burdens within their ju-

\footnotetext{
${ }^{7}$ See Becker et al. (2016); Lowes et al. (2015); Acemoglu et al. (2015); Bukowski (2016); Oto-Peralías and Romero-Ávila (2014); Grosjean (2014); Spolaore and Wacziarg (2013); Alesina et al. (2013); Voigtländer and Voth (2012); Acemoglu et al. (2011); Nunn and Wantchekon (2011); Luttmer and Singhal (2011); Grosjean (2011); Tabellini (2010); Dell (2010); Fernández and Fogli (2009); Nunn (2008); Tabellini (2008); Guiso et al. (2008); Giuliano (2007); Acemoglu et al. (2002, 2001).

${ }^{8}$ Of course, depending on what sorts of activities civil society engages in, it could also have led to very negative experiences, as in Satyanath et al. (2013).

${ }^{9}$ Porter, 1993, p. 4-5; Lieberman, 2003, p. 381-384; Woodside, 1971, p. 156-157; Thien, 2003, p. 53

${ }^{10}$ Meyer and Nguyen, 2005, p. 103

${ }^{11}$ Cotter, 1968, p. 16

${ }^{12}$ Haines, 1984, p. 309; Yu, 2001, p. 165; Lieberman, 2003, p. 382; Porter, 1993, p. 4-5
} 
risdiction. ${ }^{13}$ The village maintained multiple population and property lists for the central state, and cadastral records allowed for periodic land redistribution, as well as the collection of property taxes beginning in the 1690s. ${ }^{14}$ The state also entrusted the village with the supervision of public works. ${ }^{15}$ Historical consensus holds that Dai Viet state capacity was "exceptionally penetrating by Southeast Asian standards." 16 Comparing Vietnam to Cambodia, Laos, and Thailand, Victor Lieberman (1993, p. 484) argues: "Chinese bureaucratic norms...tended to encourage in that country [Vietnam] a more impersonal, territorially uniform, and locally interventionist system than was found in Indianized polities to the west."

Over hundreds of years, Dai Viet expanded southward (Figure 1). Through its conquests it sought to make conquered territories integral to the Vietnamese state. While conquered areas were initially settled as military colonies, they were ultimately converted into Vietnamese administrative villages, whose citizens had the same rights and obligations as areas that had been part of Dai Viet for much longer. ${ }^{17}$ The Vietnamese first conquered the fragmented, patron-client state Champa, which ruled central Vietnam through a system of loose personalistic alliances. ${ }^{18}$ The Cham had been fully absorbed by the late 17 th century (Figure 1), bringing the Vietnamese into conflict with the larger and more militarily powerful Khmer (Cambodian) empire to the south.

Dai Viet left behind a rich paper trail that historians have used to develop a nuanced understanding of local and national political economy. In contrast, the absence of a recordkeeping state in the Khmer periphery has resulted in very little quantifiable knowledge about life on the Khmer frontier prior to Vietnamese invasion. ${ }^{19}$ Nevertheless the general features of Khmer society are reasonably well-understood. The Khmer lacked a centralized bureaucracy, and the state's control over the periphery was weak. ${ }^{20}$ Southeast Asian historian Shawn McHale (2013) argues that the Khmer periphery in Vietnam was the lowland equivalent of highland Zomia in James Scott's The Art of Not Being Governed: an area with limited state capacity where peasants could escape the exactitudes of the state.

In Khmer, political appointments and land distribution were personalistic, and taxation was controlled by a temple-based system. ${ }^{21}$ Land-owning elites solidified their claims to land by building a temple. They used the temple to collect tribute from peasants and in turn passed a share up to higher level elites, who legitimized their claims to land. ${ }^{22}$ Royal

\footnotetext{
${ }^{13}$ Lieberman, 2003, p. 393; Zottoli, 2011, p. 10; Woodside, 1971; Porter, 1993, p. 5-6

${ }^{14} \mathrm{Yu}, 2001$, p. 165; Li, 1998, p. 49-56; Pastor, 1997

${ }^{15}$ Mus, 1949, p. 266

${ }^{16}$ Lieberman, 2003, p. 382

${ }^{17}$ Nguyen, 1985 , p. 8-9

${ }^{18}$ Lieberman, 2003, p. 393

${ }^{19}$ Hall, 1968, p. 121-123,126

${ }^{20}$ Tarling, 1999, p. 231-234; Ebihara, 1984, p. 282; Osborne, 1966, p. 4

${ }^{21}$ Osborne, 1969; Sahai, 1970, p. 139-148; Chandler, 1983

${ }^{22}$ Lieberman, 1993, p. 227; Hall, 2011, p. 162; Tarling, 1999
} 
patronage, not administrative specialization, were driving features of government service. ${ }^{23}$ Moreover, while Dai Viet had a law code with nearly 1000 articles - 15 percent of them aimed at protecting the existence of independent farmers - the Khmer legal code focused instead on the preservation of patron-client relations. ${ }^{24}$ Table 1 summarizes key differences between the Khmer and Vietnamese states.

Dai Viet and Khmer are representative more generally of Northeast and Southeast Asian civilizations. ${ }^{25}$ The literature commonly divides Asian societies into two groups - the Indic states of Southeast Asia and the Sinic states of Northeast Asia. Dai Viet, Korea (Choson), and Japan adopted a Chinese-style administrative bureaucracy, including the exam system. ${ }^{26}$ They had Chinese-style legal norms, a high degree of centralization, and the village was a fundamental administrative unit. $^{27}$ All three had a tributary relationship with China at some point, with political ties precipitating the adoption of Chinese statecraft. ${ }^{28}$

In contrast, a large literature on state formation in Southeast Asia classifies Laos, Siam (Thailand), Bagan (Myanmar), and Khmer, as well as states such as Srivijaya and Majapahit in island Southeast Asia, as Indianized "mandala" states. ${ }^{29}$ Since at least the second century, most states across mainland and island Southeast Asia were impacted by Hindu-Buddhist statecraft and elite culture imported from India. Bureaucracies, to the extent that they did exist, were never professionalized, even in the more centralized of the Indic polities and periods; central states had weak control over the periphery; and the village was not typically a fundamental administrative unit. ${ }^{30}$ The lines between private and state affairs were blurred, and regime stability depended largely on monarchical personality politics, as opposed to the codified rules of succession seen in China. ${ }^{31}$ Southeast Asian states also shared common Buddhist-Hindu legal origins, though Islamic tradition eventually influenced Indonesia and Malaysia. ${ }^{32}$ Legal codes tended to emphasize the preservation of patron client relations, which some scholars have argued is due to the influence of the Indian caste system. ${ }^{33}$

Mere decades after the organization of the Khmer areas as Vietnamese provinces in 1833, the French began colonizing Vietnam. Our study region belonged entirely to the directly administered province of Cochinchina, established in 1862. The French method of extracting

\footnotetext{
${ }^{23}$ Mabbett and Chandler, 1995, p. 166-167; Ebihara, 1984, p. 285; Mabbett, 1978, p. 10

${ }^{24}$ Ebihara, 1984, p. 285-286; Woodside, 1984, p. 318-319; Haines, 1984, p. 310

${ }^{25}$ Hall, 1973; Cotterell, 2014

${ }^{26}$ Woodside, 1971; Woodside, 2006; Liu, 2007

${ }^{27}$ Jansen, 2000; Barnes, 2007; Liu, 2007; Lewis, 2009; Lewis, 2011; Kang and Cha, 2010; Whitmore, 1979; Palais, 1996

${ }^{28}$ Kang and Cha, 2010; Kang, 2010

${ }^{29}$ Co dès, 1966; Mabbett, 1977a; Kulke, 1986; Tambiah, 1977; Wolters, 1999; Tambiah, 2013

${ }^{30}$ Lieberman, 1993; Lieberman, 2003

${ }^{31}$ Lieberman, 1987; Chutintaranond, 1990

${ }^{32}$ Hooker, 1978b; Hooker, 1978a; Harding, 2001; Acharya, 2013

${ }^{33}$ Mabbett, 1977b
} 
surplus varied with the pre-existing institutions. ${ }^{34}$ Where existing village structures were strong and deeply rooted, they could be leveraged to meet extractive aims. ${ }^{35}$ In contrast, where the village was weak and already lacked legitimacy, village leaders lost further legitimacy in attempting to collect taxes for the French. The French relied on externally appointed officials to facilitate tax collection, and French landowners took control of many estates that had previously been held by the Khmer landed gentry. ${ }^{36}$ We digitized data on all French landownership in Vietnam at the close of the colonial period, and $97.5 \%$ of French lands in Vietnam were on the Khmer side of the boundary. ${ }^{37}$ Nearly all of these lands are further south than our study region, and thus are unlikely to explain our results, but the overall patterns support the assertion that the French worked through existing societal structures.

French colonial strategy halted the Vietnamization of former Khmer territories that would have otherwise plausibly taken place. If the historical state had differed, colonial policy would have as well, as it exploited and preserved pre-existing norms. Colonial policy is hence an outcome that is important for understanding persistence, not just in Vietnam but in a variety of Asian countries that also experienced foreign interference.

Following World War II, the Vietnamese engaged in a successful anti-colonial struggle against the French. The Geneva Accords of 1954 demarcated Vietnam at the 17th parallel into two zones - communist North Vietnam and pro-western South Vietnam - until elections to be held in 1956 would select a unified Vietnamese government. These elections never occurred, and ongoing conflict gradually escalated into the Vietnam War. Our study region is well within South Vietnam, with the 17th parallel falling near the boundary of the northernmost region in Figure 1. Importantly for our study, in 1967 there was a major constitutional reform in South Vietnam that decentralized political power, granting villages new budgetary powers, control over local councils, and the ability to elect village councils and shape local development projects. Our results from the South Vietnamese era thus shed light on the impacts of the historical state in a context with a high degree of decentralization.

In 1975, Vietnam was reunited under a communist government, which attempted unsuccessfully to collectivize land in the south and implement a command economy. Liberalization began in the 1990s, and presently Vietnam is one of the more decentralized countries in Southeast Asia. An administrative hierarchy defines a fiscal relationship between the village and the central government, with provincial and district bodies in between. Fiscal administration is conducted at the provincial level, whereas village governments continue to play a role in administering a variety of services. ${ }^{38}$ Officials are selected by communist

\footnotetext{
${ }^{34}$ Nguyen, 2003, p. 117; Booth, 2007

${ }^{35}$ Nguyen, 1985 , p. 160

${ }^{36}$ Nguyen, 2003, p. 119; Osborne, 1969, p. 151; Popkin, 1979, p. 432; Wolf, 1969, p. 177

${ }^{37}$ These data were compiled from French records by the Stanford Research Institute (Bredo, 1968).

${ }^{38}$ See Kerkvliet and Marr (2004).
} 
party bodies. ${ }^{39}$ However, locally selected village heads continue to exist in a more informal capacity, carrying out important de facto functions in local politics along with village-level party officials, although the central government does not formally recognize them. ${ }^{40}$

\subsection{The Dai Viet - Khmer Boundary}

The 1698 boundary between Dai Viet and Khmer is the southernmost one in Figure 1, shown with a thick black line. Areas just to the east of this boundary were part of Dai Viet for around 150 years prior to French colonization, whereas areas just to the west were organized under Vietnamese administrative lines in 1833, just decades prior to the commencement of French colonization. Dai Viet exercised a strong control over its periphery, and the Vietnamese state believed "firmly in well-defined borders as an alternative of wayward conquering." 41 Systematic data do not exist for this region prior to Vietnamese conquest. Nevertheless, the historical evidence suggests that the location of the boundary is the result of a highly contingent set of historical circumstances that with small perturbations would have produced different boundaries, as opposed to reflecting underlying economic potential.

Upon completion of the conquest of Champa, southern expansion brought Dai Viet into conflict with the Khmer kingdom. In 1623, the Vietnamese procured the rights from Khmer to establish a customs house at Prey Nokor (today Ho Chi Minh Port), which was at the time a small Khmer fishing village. Prey Nokor historically played a marginal role in Southeast Asian trade and "would only become important much later when it had been developed as an administrative center [of Dai Viet]." 42 Other natural ports such as Ha Tien, Ninh Kieu, and Binh Long were located on the Khmer side of the boundary and initially played a larger role in trade. Throughout the 17th century, Vietnamese settlers fleeing civil conflict in Vietnam moved into the surrounding region. ${ }^{43}$ The Vietnamese annexed much of the eastern Mekong as Gia Dinh Province in 1698, in part using rivers to demarcate the territory, and the Khmer crown was unable to stop this since they were engulfed in a war with Thailand. Dai Viet then set about consolidating the area into administrative districts. ${ }^{44}$

Dai Viet would have likely annexed further Khmer territory in the immediate aftermath of 1698 , but this process was halted due to a contingent set of circumstances at home. ${ }^{45}$ Vietnam had witnessed a series of bloody civil wars between the Nguyen family in the south and the Trinh family in the north. In 1672, a truce was declared, and the country was split

\footnotetext{
${ }^{39}$ Marr, 2004, p. 48

${ }^{40}$ Kerkvliet and Marr, 2004, p. 4-7

${ }^{41}$ Osborne, 1969, p. 13

${ }^{42}$ Vickery, 1996, p. 415; Parthesius, 2010

${ }^{43}$ Cœ dès, 1966; Taylor, 2013, p. 303-310

${ }^{44}$ Briggs, 1947, p. 358

${ }^{45}$ Nguyen, 1999, p. 17
} 
in two. Conquering a more substantial chunk of Khmer territory further south would have required a full-scale offensive by the Nguyen army against Khmer and Thailand, which also aspired to conquer Cambodia. ${ }^{46}$ This would have left the Nguyen vulnerable to an attack in the north from the Trinh. Civil conflict likewise constrained the Khmer state, which had been in decline since the 15th century. The Khmer crown oscillated between pro-Siamese and pro-Vietnamese royal factions in a series of bloody conflicts. ${ }^{47}$ Vietnamese had settled in the Khmer areas during the 18th century, albeit with a risk of ethnic cleansing, but they did not have the political rights and obligations of those residing in Dai Viet. ${ }^{48}$ This political equilibrium persisted until the latter quarter of the 18th century, when large-scale conflict in Vietnam broke out. The Nguyen, who governed the south, united all of Vietnam under their rule in 1802, allowing the annexation of the remainder of modern Vietnam to proceed.

\section{Estimation Framework}

This study's research design exploits the discontinuous change in exposure to the historical state across the Khmer-Dai Viet boundary, comparing households in areas incorporated into Dai Viet in 1698 to households in areas that remained under Khmer. The boundary forms a multi-dimensional discontinuity in longitude-latitude space, and regressions take the form:

$$
\text { out }_{v}=\alpha+\gamma \text { Dai Viet }_{v}+f\left(\text { geographic location }_{v}\right)+\sum_{i=1}^{n} \operatorname{seg}_{v}^{i}+\beta \text { dist_hcm }_{v}+\epsilon_{v}
$$

where out $_{v}$ is the outcome variable of interest in village $v$, and Dai Viet ${ }_{v}$ is an indicator equal to 1 if village $v$ was on the Dai Viet side of the 1698 boundary and equal to zero otherwise. $f$ (geographic location l ) is the RD polynomial, which controls for smooth functions of geographic location. The $s e g_{v}^{i}$ split the boundary into $25 \mathrm{~km}$ segments and equal 1 if village $v$ is closest to segment $i$ and zero otherwise. The boundary segment fixed effects ensure that the specification is comparing villages across the same segment of the boundary, and the appendix shows that results are highly robust to the choice of segment length. Finally, dist_hcm $_{v}$ is the distance of village $v$ from Ho Chi Minh City and is included in all regressions to explicitly control for proximity to the region's largest urban area. For regressions with equivalent household consumption on the left-hand side, we also include a vector of demographic variables giving the number of infants, children, and adults in the household.

The baseline specification limits the sample to villages within 25 kilometers of the thresh-

\footnotetext{
${ }^{46}$ Nguyen, 1999, p. 17

${ }^{47}$ Wook, 2004, p. 293

${ }^{48}$ Taylor, 2013, p. 325-336; Engelbert, 1994, p. 170-175
} 
old. Following Gelman and Imbens (2014), we use a local linear RD polynomial for the baseline and document robustness to a wide variety of different bandwidths and RD polynomials.

The key identifying assumption is that all relevant factors besides treatment vary smoothly at the Dai Viet-Khmer boundary. That is, letting $c_{1}$ and $c_{0}$ denote potential outcomes under treatment and control, x denote longitude, and y denote latitude, identification requires that $E\left[c_{1} \mid x, y\right]$ and $E\left[c_{0} \mid x, y\right]$ are continuous at the discontinuity threshold. This assumption is needed for observations located just across the Khmer side of the boundary to be an appropriate counterfactual for observations located just across the Dai Viet side.

To assess the plausibility of this assumption, Table 2 examines a variety of geographic characteristics, using gridded geographic data and regressions of the form described in equation (1). The unit of analysis is a $10 \mathrm{~km}$ x $10 \mathrm{~km}$ grid cell. ${ }^{49}$ To be conservative, we treat grid cells as independent observations, as the use of spatially correlated standard errors tends to slightly increase their magnitude. Ideally we would be able to look at social and economic characteristics before Dai Viet settled our study region, during the period when the entire area was loosely controlled by Khmer. However, because the state was weak, no systematic data were collected. Suitability for rice - the dominant crop - was plausibly the most relevant characteristic given the agrarian nature of the society at that time.

Columns (1) and (2) of Table 2 examine elevation and slope, respectively. The point estimates on Dai Viet are small relative to the mean and statistically insignificant. Column (3) shows that temperature is likewise balanced. Column (4) does find a modest difference in precipitation that is marginally significant at the $10 \%$ level, but the coefficient is quite small relative to the mean. Column (5) documents that suitability for rice - the region's principal crop - is similar on either side of the boundary. Column (6) examines flow accumulation, a measure constructed by the USGS Hydrosheds project that calculates how many cells are uphill from the cell under question. The higher the number, the more water we would expect to flow through the cell. There is not a statistically significant difference. Finally, column (7) examines the kilometers of river flowing through each cell, which is also balanced.

An additional assumption is no selective sorting across the treatment threshold. This would be violated if the historical state provoked substantial out-migration of relatively productive individuals from Khmer to Dai Viet, leading to a larger indirect effect. The historical state would still exert long-run impacts, but the interpretation would be different. As Dai Viet expanded southward, it initially set up military colonies in newly acquired areas with settlers from the north. This process happened throughout southern Vietnam prior to the arrival of the French. However, there is little evidence of selective migration from Khmer to established Dai Viet villages. The historical literature argues that negative attitudes towards outsiders created substantial barriers to moving into established villages:

\footnotetext{
${ }^{49}$ Results are similar when other sized cells or villages are used as the unit of analysis.
} 
"An outsider who was allowed to live in a village had fewer rights to village possessions than did insiders. His descendants, furthermore, might not receive full citizenship-and with it, the right to own property and be notables-for several generations. Such marked distinctions made it exceedingly difficult, if not impossible, for a man to move into a village and take over another man's land. Even well into the period of French rule, a person from another village who tried to farm was likely to have his crops destroyed...The emphasis on village citizenship, therefore, encouraged local ownership" (Popkin, 1979, p. 89).

Moreover, the Pacification Attitudes and Analysis Survey, conducted in the early 1970s, asked individuals if they would hypothetically be willing to move to a different village or province if they received an offer for a higher paying job. Only $21 \%$ and $12 \%$ of respondents answered yes, respectively.

Finally, we use the 2009 census to compare current place of residence to place of residence in 2004 and find low levels of migration between historically Khmer and Dai Viet areas. $2.5 \%$ of households in areas historically under Dai Viet reported having lived in historically Khmer areas in 2004. 1\% of households in historically Khmer areas reported having lived in historically Dai Viet areas in 2004. While migration is unlikely to be a primary driver of results, we will examine its potential effect on the estimates in Section 4.

\section{Long Run Effects on Economic Prosperity}

This section examines the impacts of the historical state on economic prosperity across the past century and a half. It begins by considering effects on contemporary household consumption and then explores a variety of historical measures of economic activity.

The biennial Vietnam Household Living Standards Surveys (VHLSS) were collected between 2002 and 2012 by the General Statistics Office of Vietnam with technical assistance from the World Bank. ${ }^{50}$ The set of sampled villages remains mostly constant across 20022008 , and then changes substantially in 2010. In each year, a core survey is administered to a large number of households, and an additional module on expenditures is administered to a subsample of households. In order to create a panel, there is a $50 \%$ rotation of households from one survey round to the next. To avoid repeated observations for the same household, we drop all households in 2004 that were also surveyed in 2002, all households in 2006 that were also surveyed in 2004 and so forth. Results are quantitatively similar if all observations are retained (Appendix Table A-1). To construct a measure of consumption that reflects

\footnotetext{
${ }^{50}$ The survey was collected during the 1990s but only for a very small sample of villages.
} 
productive capacity, we subtract transfers received from total consumption, though estimates are similar when transfers are included (Table A-2). ${ }^{51}$

Table 3 reports estimates from equation (1), using the log of equivalent household consumption as the dependent variable. Following Deaton (1997), we assume that children aged 0 to 4 are equal to 0.4 adults and children aged 5 to 14 are equal to 0.5 adults. All regressions control for survey year fixed effects and the number of household members aged 0-4, $5-14$, and 15 and older. ${ }^{52}$ Standard errors are clustered at the village level, and none of the significance levels in Table 3 change if errors are clustered at a higher administrative level or adjusted for spatial dependence.

Overall, the point estimates suggest that household consumption is around a third higher in Dai Viet villages. Column (1) uses a local linear polynomial in latitude and longitude, whereas column (2) uses instead a local linear polynomial in distance to the boundary, and column (3) includes both. Results are similar across these specifications. In a regression discontinuity there are many options for how to specify the RD polynomial and bandwidth. We follow Gelman and Imbens (2014) in specifying the baseline as a local linear polynomial but are not aware of a widely accepted optimal bandwidth for a multi-dimensional RD, employing a variety of outcomes. Fortunately the choice of bandwidth and RD polynomial makes little difference. Each panel in Figure 2 plots point estimates of $\gamma$ using equation (1) and different bandwidth values between 10-100 kilometers, with the bandwidth under consideration denoted on the x-axis. Thin lines show $95 \%$ confidence intervals while the slightly thicker lines show $90 \%$ confidence intervals. The panels in different rows employ different functional forms for the RD polynomial: linear latitude-longitude polynomial (row 1), linear distance to the boundary polynomial (row 2), both linear latitude-longitude and linear distance to the boundary polynomials (row 3), and analogous specifications using quadratic functional forms (rows 4 through 6 ). The estimates in the first column include the full border and show that impacts are remarkably robust to alternative bandwidth and RD polynomial choices, though by construction estimates for smaller bandwidths tend to be noisier, particularly for quadratic polynomials. The second column shows that estimates change little when limiting the sample to portions of the boundary not formed by rivers.

The results can be seen graphically in Figure 3. Each sub-figure shows a scatter plot for one of the paper's main outcomes. These plots are the three-dimensional analogues to standard two-dimensional RD plots, with each village's longitude on the x-axis, its latitude on the y-axis, and the outcome shown using an evenly-spaced monochromatic color scale. The background shows predicted values, for a finely spaced grid of longitude-latitude coordinates,

\footnotetext{
${ }^{51}$ We classify transfers as remittances and gifts received by the household as well as all income from social welfare and charity organizations.

${ }^{52}$ Household demographics are balanced.
} 
from a regression for the outcome under consideration using equation (1). In the typical RD, the predicted value plot is a two-dimensional curve, whereas here it is a three-dimensional surface, with the third dimension indicated by the color gradient. Lighter shades indicate higher values. The data are not binned, the way they often are in a two-dimensional RD, so will tend to show greater variation. Panel (a) for household consumption illustrates the predicted jump across the boundary and darker dots tend to overlay darker-shaded areas, indicating a good fit.

The cluster of points on the Dai Viet side of the boundary is Ho Chi Minh City, and one concern is that it drives the effects. Its placement is not by chance - it was the administrative center of Dai Viet's 1698 expansion - but if it drove the results the interpretation would be different. While Ho Chi Minh City is near the boundary, it does not directly border the boundary, and hence its influence on the RD estimates is limited. Column (4) shows that results barely change upon dropping all urban districts comprising Ho Chi Minh City, and column (5) documents that results are also unchanged when all of Ho Chi Minh Province which includes urban and rural areas - is excluded. Column (6) shows that results are also robust to dropping all provincial capitals, which largely removes urban areas.

Villages in Dai Viet do tend to be slightly closer to Ho Chi Minh City, but this does not change discontinuously at the boundary. Hence, the RD controls for it. One additional concern, though, is that travel costs could be discontinuous along boundary segments formed by rivers - today bridges are widespread but this may not have always been true. On the other hand, river segments might be preferred to the extent that they constitute exogenous barriers that were used to separate different historical polities. Column (7) limits the sample to villages closest to boundary segments that do not coincide with rivers, and column (8) does the same for segments that are formed by rivers. The point estimates are of similar magnitude, suggesting that effects are unlikely to be driven by discontinuous travel costs or by unobservables that change discontinuously only along non-river segments. This robustness extends across bandwidths and RD polynomials (Figure 2). Another alternative hypothesis is that results could be driven by higher levels of government. Provinces change across the study period, so we aggregate these changes to create provinces with consistent boundaries across time. Comparing villages within these if anything makes the estimates larger (column $9)$.

An additional question to consider is whether differential rates of migration today may be responsible for living standards differences across the boundary. Given that in-migration to provinces historically under Dai Viet is about 2.5\%, we omit the $2.5 \%$ of the Dai Viet sample with the highest consumption. To be conservative we similarly omit the $1 \%$ of the Khmer sample with the lowest consumption, as in-migration to Khmer areas is $1 \%$. The estimate in Column (10) based on the trimmed sample remains similar, indicating migration 
today is not large enough to drive the differences. We have no way to measure migration - or how selective it was - historically. However, as discussed in Section 3, the fact that migrants and their descendants faced substantial barriers in gaining full village citizenship suggests that selective migration is unlikely to fully drive our results.

A final concern is that the boundary may be an unusual place. We address this by examining two alternative samples. The first considers only places $25-100 \mathrm{~km}$ from the boundary, omitting the boundary region itself. The second compares all of South Vietnam that belonged to Dai Viet historically to all of South Vietnam that belonged to Khmer. ${ }^{53}$ While these estimates are no longer causally identified, they remain very similar to the baseline estimates, demonstrating that the effects near the boundary are not a fluke. Results (available upon request) are also robust to dropping other places that may be unusual, such as coastal villages.

The appendix documents additional robustness. The baseline specification uses $25 \mathrm{~km}$ boundary segment fixed effects. Appendix Tables A-3 through A-6 show robustness to instead including 100, 75, 50, or $10 \mathrm{~km}$ segment fixed effects, respectively. Tables A-7 and A-8 document that results are broadly similar before and after the redefinition of the VHLSS sample in 2010.

Finally, Appendix Table A-9 reports several placebo tests. First, the rivers coinciding with the Dai Viet boundary also flow through areas that are not along the boundary (Appendix Figure A-1), providing an additional opportunity to examine whether estimates simply capture the effect of being on different sides of a river. Column (1) estimates the baseline regression on the sample of districts bordering other portions of the rivers that partially form the boundary, assigning as treated whichever side of the river segment is richer. The difference across the rivers is statistically insignificant. Column (2) performs a placebo comparing across the provincial boundaries in the study area, in order to see whether income differentials of the magnitude found along the Dai Viet boundary are typical. This requires assigning some places as treated and others as untreated, and in order to stack the test in favor of finding a difference we assign the richer side of each provincial boundary segment as treated. The specification does not reveal a statistically significant discontinuity. Finally, Column (3) considers a placebo test using other historical boundaries of Dai Viet's southward expansion. To increase power, we pool all observations in proximity to the 1306, 1407, 1471, 1611, 1651 and 1693 boundaries, and the treatment indicator equals 1 if the district is located on the side of the boundary conquered earlier. Since all of these places were organized under the village government system for hundreds of years, we would expect there

\footnotetext{
${ }^{53}$ We focus on South Vietnam to increase comparability, since the North had a very different history under Communist North Vietnam between independence and reunification. We do not include an RD polynomial since the sample contains places very far from the boundary, but estimates are larger when it is included.
} 
to be little or no long run effect of being brought into this system modestly earlier. This contrasts to the Khmer-Dai Viet boundary, where villages on the Khmer side were organized along Dai Viet administrative lines for only a short time before French colonization. The estimate is indeed small and statistically insignificant.

The historical state has a robust impact on current living standards. We turn next to an examination of economic variables across the past century and a half, in order to examine whether similar effects obtain historically. Data from the pre-colonial period are not systematically available, in particular for the Khmer side of the boundary. When the French arrived, they did collect some systematic data, but disaggregated data are rare. The only source of extant village level information is maps held by the Bibliotheque Nationale de France, for 1878, 1901, 1910, and 1926. Each map shows different types of infrastructure - specifically roads, railroads, telegraph lines, and military posts - though not all types of infrastructure are shown in all maps. Since our entire study region is within the same colonial administrative unit, Cochinchina, we would not expect these outcomes to differ if pre-existing conditions were not different. The colonial state and private companies plausibly invested in transport and communications infrastructure in areas with the greatest economic surplus. We georeferenced these maps and intersected them with village boundaries.

Table 4, columns (1) and (2) consider density (in km per village area) of telegraph lines in 1878 and 1901, respectively. Telegraph lines were more prominent on the Dai Viet side of the boundary, and the coefficients are large relative to the sample means. In contrast, while only $3 \%$ of villages in the sample contain a military post, these were less prominent in 1878 in Dai Viet areas, plausibly because these villages could be more easily governed through the pre-existing village structure (column 3). The 1878 map also shows lines denoting a rail or road (of any type), and there is not a statistically significant difference across the boundary (column 4). However, by 1910, the maps reveal that railroad density was higher in Dai Viet villages (column 6), and the coefficient on motor roads (which may be paved or unpaved) is positive but noisy (column 5). Finally, the 1926 map shows a strong positive effect on paved roads (column 7). The railroad effect, in contrast, is no longer statistically significant, and the density of railroads by this time had fallen nearly in half relative to 1910 (column 8). Appendix Figure A-2 shows that these estimates are broadly robust to the choice of bandwidth. We plot coefficients only for the linear RD baseline specification, to avoid reporting tens of thousands of coefficients over the course of the study, but estimates are also similar when other RD polynomials are used.

Next, we turn to data from the South Vietnamese period. Income data are available for a sample of hamlets through the Pacification Attitudes and Analysis Survey (PAAS, U.S. National Archives RG 330 and 472). PAAS was a joint U.S.-South Vietnamese effort, in which responses were compiled by Vietnamese enumerators. It was launched in March 
of 1970 and was conducted monthly until December of 1972, though unfortunately not all months have been preserved. ${ }^{54}$ Each month, surveys were conducted in 6 randomly selected hamlets per province. 15 respondents were randomly selected per hamlet, with stratification on demographic characteristics. The survey focused on citizens' attitudes and opinions, but also asked about household income in the past year. Households identify which income bin describes their situation, and we assign their income as the midpoint of the bin. The data are not of the same quality as modern expenditure surveys but are nevertheless a rare example of income measurement in a developing country before the advent of living standards surveys.

We also obtain a variety of economic indicators from the Hamlet Evaluation System (HES, RG 472), collected jointly by the United States and South Vietnam between 1969 and 1973. HES contains information on economic, social, political, and security conditions in all South Vietnamese hamlets, with data collected on a quarterly basis. ${ }^{55}$ The information was compiled by US and Vietnamese advisers, in conjunction with local officials, and the questions are at the hamlet or village level. The data provide unusually rich local level information covering a broad set of variables.

The HES questions have categorical responses. We code questions with multiple responses into binary indicators that preserve variation (see the data appendix for more details). For example, a coding of a question about non-rice food availability into no or limited availability versus ample availability preserves significantly more variation than alternative codings, since few hamlets completely lack non-rice staples. ${ }^{56}$ These indicators are then averaged across the full period of data availability. We also report estimates from a Bayesian latent class analysis, to address potential concerns about the coding of categorical responses and multiple hypothesis testing. Based on the observed categorical responses to all economic questions, latent class analysis estimates the posterior probability that each hamlet belongs to one of two latent groups associated with "high" and "low" economic prosperity. ${ }^{57}$

Estimates for economic outcomes during the South Vietnamese period are reported in Table 5. Column (1) examines log household income between 1970 and 1972. Income on the Dai Viet side of the boundary is around 16 percentage points higher, and the estimate is statistically significant at the $1 \%$ level. Column (2) documents that hamlets historically under Dai Viet are 16 percentage points more likely to be in the high prosperity latent

\footnotetext{
${ }^{54}$ Tapes containing information for May, 1970 through February, 1971 and for August and September of 1971 were not preserved.

${ }^{55}$ Most questions are quarterly, but a few of the security questions were collected monthly.

${ }^{56} \mathrm{An}$ alternative would be to estimate a multinomial logit, but this does not converge well since there is often little variation in some of the categories.

${ }^{57}$ We include questions that are available for the full sample period. Results are similar if we include questions that were only asked during part of the sample period. When we compute the LCA, we include all observations, to avoid needing to recompute the LCA when changing the bandwidth. However, if we just include hamlets within 25 kilometers of the boundary in the LCA computations, results are very similar.
} 
class $($ s.e. $=0.055)$, and the effect is significant at the $1 \%$ level. See also Figure 3, panel b). The results for the individual outcomes that contribute to the LCA show a similar pattern. In places with a strong state historically, non-rice foodstuffs are 28 percentage points more likely to be amply available (column 3, s.e.=0.06), and manufactured goods are 20 percentage points more likely to be available (column 4 , s.e. $=0.07$ ). Surplus goods are also more likely to be produced, households are less likely to require assistance to subsist, and households are more likely to have access to a vehicle (columns 5-7). However, there is no difference in whether land is left fallow due to poor security (column 8). The next section will show that security did not differ substantially across the Dai Viet boundary, alleviating the concern that these effects could be largely driven by the war. Finally, column (9) shows that there is no difference in quarterly population growth, suggesting that differential migration during this period is unlikely to contribute substantially to the effects. Appendix Figure A-3 documents that results are broadly robust to the choice of bandwidth.

One concern is that the results could be partially driven by hamlet size. While we do not control for this in the baseline, since it is endogenous, Table A-10 documents that results are similar when this control is included. Results are also similar when we drop Ho Chi Minh City, which at the time was its own province, or when we drop all provincial capitals (Tables A-11 and A-12).

Finally, we digitized district level data on land ownership and rice cultivation during 19751985, the period after Vietnamese reunification, from provincial yearbooks and declassified Vietnamese Communist Party documents. The main drawback of these data is that there are relatively few districts, and thus we lack statistical power. In order to have enough observations for regression analysis, we extend the bandwidth to 100 kilometers. Estimates in Table A-13 suggest that districts in historically Dai Viet areas had a higher share of state-owned land, a lower share of private land, and may have had less land cultivated with paddy rice. ${ }^{58}$ Conditional on land being in paddy, it was more likely to be irrigated and mechanized. Most effects are marginally significant at the $10 \%$ level, except the effect on land in paddy, which falls short of statistical significance but is large in magnitude. While these effects are noisy, they are highly consistent with the persistent impacts of the historical state on economic conditions, documented from the mid-19th century through the present.

\section{Mechanisms}

This section explores mechanisms through which the historical state has influenced longrun development. Our hypothesis is that Dai Viet's long history of village government

\footnotetext{
${ }^{58}$ In addition to state and private land, the third category of land is collectively farmed land. In 1979, when these data were compiled, there was no collectively farmed land in our study region.
} 
translated into greater local collective action that has persisted through a series of upheavals following the dissolution of Dai Viet, including colonial conquest, the Vietnam War, and an effort to implement a communist command economy. Long after the Dai Viet central state ceased to exist - and even in the face of subsequent state policies that have at times aimed to discourage local collective action - these norms have persisted and have plausibly had important impacts on local public goods provision and economic development. We do not claim that local collective action is the only mechanism linking the historical state to long-run development, but the historical and empirical evidence make it difficult to tell a story where it does not play an important role.

Before examining the data in detail, it is useful to consider one important reason local collective action may vary across the boundary - ethnic heterogeneity. ${ }^{59}$ In the past ethnicity may well have differed, but more recently the vast majority of people throughout the region self-identify as Vietnamese. In VHLSS, $97 \%$ of respondents are Vietnamese and almost none identify as Khmer or Cham. The only minority group of any quantitative significance is the Chinese, who are concentrated in large urban areas. Results change little when these areas are dropped. Within villages, there is almost no ethnic diversity. Moreover, during the 1960s and 1970s, Vietnamese is identified as the primary ethnicity in over $98 \%$ of hamlets. While it is possible that individuals could self-identify as Vietnamese but still practice the customs of other ethnic groups, we do not find differences across the boundary in patrilocal marriage patterns, an important difference between Northeast and Southeast Asian ethnicities.

Engagement with civil society and local government - two important components of local collective action - is often unobserved, particularly historically, but between 1969 and 1973 the U.S. and South Vietnamese governments compiled unique local level data on civil society, village government, and public opinion. The Hamlet Evaluation System (1969-1973) contains monthly and quarterly data on economics, civil society, local government, and security for nearly all of South Vietnam's 18,000 hamlets, and the PAAS Public Opinion Survey (19701972) provides public opinion data for a random sample of hamlets. These data are described in more detail in the previous section.

Table 6 uses the HES data to examine non-communist civil society (the Viet Cong insurgency will be considered subsequently). To address potential concerns about multiple hypothesis testing, we start by constructing a summary measure using Bayesian latent class analysis and the individual civil society questions, as described in the previous section. The dependent variable in column (1) is the posterior probability that the hamlet is in the high civil society group. Hamlets historically under a strong state are 18 percentage points more likely to be classified in the high group $($ s.e. $=0.035)$, relative to a sample mean posterior

\footnotetext{
${ }^{59}$ See Bazzi and Gudgeon (2016); Montalvo and Reynal-Querol (2005b,a); Alesina and La Ferrara (2005); Alesina et al. (1999); Easterly and Levine (1997).
} 
probability of 0.76. This effect is shown in Figure 3, panel c).

Columns (2) through (12) consider individual outcomes. In hamlets historically under Dai Viet, households are 26 percentage points more likely to participate in civil organizations, relative to a sample mean of 0.37 and are 21 percentage points more likely to participate in local economic trainings (columns 2-3). Both effects are significant at the one percent level. Households in Dai Viet villages are 8 percentage points more likely to participate in the People's Self Defense Forces - a local self defense organization - and the effect is statistically significant at the one percent level (column 4). Dai Viet villages are also substantially more likely to have self-development projects underway (column 5). We do not find that the village council is more likely to discuss citizens' grievances with them - the mean of this variable is over $90 \%$ - nor are Dai Viet villages more likely to have organized youth activities (columns 6-7). Dai Viet households are 10 percentage points more likely to attend meetings held by the village government, relative to a mean of 0.37 (column 8). In the final columns, we consider outcomes that may be selected - participation in Rural Development (RD) Cadre activities and civil organization assistance to needy households. Not all villages have RD Cadre - South Vietnamese development aid workers - or households that require assistance to subsist, but only villages that have RD cadre can participate in their activities and only villages that answer that they have households requiring assistance to subsist can then specify that they have civic organizations to provide this assistance. Otherwise, the response to these is coded as zero. ${ }^{60}$ We do not find a difference in whether the RD cadre are present in the hamlet, and in Dai Viet villages, households are more likely to participate in RD cadre-initiated development activities (columns 9-10). In contrast, Dai Viet villages are substantially less likely to have households that require assistance to subsist (column 11). Nevertheless, they are 17 percentage points more likely to have organizations that provide assistance to such households, relative to a sample mean of 0.24 (column 12). ${ }^{61}$ These results are broadly robust to the selection of bandwidth (Appendix Figure A-4), to controlling for population, to dropping Ho Chi Minh City, and to dropping all provincial capitals (Tables A-14 to A-16).

Next, we turn to local governance and public goods provision, with outcomes drawn from HES (1969-1973). During this period, a constitutional reform had decentralized many governance and public goods provision roles to the local level, making it a time when local government was particularly relevant. As discussed in the introduction, it is not clear from the existing literature whether we would expect impacts on local governance to go in the same direction as those on civil society.

\footnotetext{
${ }^{60}$ These outcomes are not included in the LCA since they may be selected, but LCA impacts would be even stronger if they were included.

${ }^{61}$ The response to this question is 0 by construction if villages don't have such households.
} 
The results indicate that local governance and civil society in Vietnam are complements. They also suggest that participatory decentralization reforms work best in areas with a history of participatory governance. Table 7, Column (1) considers the posterior probability that the hamlet belongs to the class associated with good local government administration. Dai Viet areas are more likely to be classified in the high local governance class, and the effect is statistically significant at the $5 \%$ level.

A classic measure of state capacity is tax collection, and column (2) shows that local governments in Dai Viet villages are six percentage points more likely to systematically collect taxes, relative to a sample mean of 0.84 . Column (3) documents that Dai Viet villages are also more likely to have all the positions on their village committee - which organizes public goods provision - filled. The village chief is more likely to be regularly present in Dai Viet villages, though there is not a statistically significant effect on the presence of the hamlet chief (columns 4 and 5). Moreover, police are 17 percentage points more likely to be regularly present, relative to a sample mean of 0.56 (column 6). Next we consider outcomes that might be selected - the village head's control over the RD cadre and the provision of government assistance. There is not a difference in the presence of RD cadre (Table 6, column 9), but village heads in Dai Viet villages are more likely to effectively control the RD teams (column 7). Households in Dai Viet villages are less likely to require assistance to subsist (Table 6, column 11), but despite this governments in Dai Viet villages are 14 percentage points more likely to provide assistance, relative to a sample mean of 0.3 (column 8).

Examining policies under the control of the provincial government can serve as a useful placebo. In principal, the historical state could affect provincial governments or the distribution of provincial resources, but if the mechanism is about organizing within the village we would expect these effects to be less pronounced. HES asked three questions about provincial government: whether projects have failed due to a lack of provincial technical assistance (column 9), whether provincial technical personnel - such as agricultural extension workers regularly visit the village (column 10), and whether provincial land affairs officials visit the village to assist with land reform (column 11). All coefficients are small relative to the mean and statistically insignificant.

Local public goods provision also shows a discontinuity at the Dai Viet boundary. Data are available for health care, education, and law enforcement, the principal public goods in this context. Table 8, Column (1) reports the LCA for health care provision, documenting that Dai Viet villages are substantially more likely to be in the high health care provision latent class (see also Figure 3, panel d)). Government-provided medical services are 20 percentage points more likely to be available, relative to a sample mean of 0.39 and mobile health workers are more likely to regularly visit all hamlets in the village (columns 2-3). There is more likely to be a health clinic in the village, but we do not find an impact on the 
presence of a maternity clinic (columns 4-5).

We also consider education. The LCA is not statistically significant, though it is positive (column 6). This is partially driven by the fact that there is not a difference in whether school attendance is restricted by poor security (column 11). Dai Viet villages are 6 percentage points more likely to have access to a primary school, and the primary school completion rate is 9 percentage points higher, relative to a sample mean of 0.61 (columns 7 and 8). There is not a statistically significant impact on whether there is a secondary school in the village - though the coefficient is large and positive - but the secondary school attendance rate is 3 percentage points higher, relative to a sample mean of 0.18 (columns 9 and 10). Finally, in Dai Viet villages, authorities are 22 percentage points more likely to enforce the law day and night (column 12). The local administration and public goods results are robust to alternative bandwidths, to controlling for population, to dropping Ho Chi Minh City, and to dropping provincial capitals (Figures A-5 to A-6 and Tables A-17 to A-22).

Public opinion data, examined in Table 9, can corroborate the above results with an independent data source and also provide additional nuance. Since different questions are asked in different months, the number of observations can vary substantially. Column (1) documents that respondents in Dai Viet villages are 9.8 percentage points more likely to report that their local government is responsive to the needs of its citizens, relative to a sample mean of 0.37 . They are also 20 percentage points more likely to report that their local government is successful, relative to a sample mean of 0.52 , and they have more knowledge of their village administrative structure (columns 2-3). This is consistent with the previous result that they are more likely to attend government meetings. Respondents in Dai Viet areas are also 35 percentage points more likely to feel that the Land to Tiller (LTT) program - South Vietnam's land reform - was administered fairly in their village (column 4).

These views do not extend to the national government (columns 5-6). Respondents in Dai Viet villages are 11 percentage points more likely to respond that the national government performs poorly, an effect that is significant at the one percent level. They are also more likely to feel that the national government has done a poor job of managing the economy. These results suggest that effects cannot be explained by Dai Viet areas having more positive attitudes towards government in general.

A final set of questions considers civic engagement. These have a smaller sample size and should be interpreted cautiously. Respondents are asked who has the primary responsibility to make community life better, the people or the government, and respondents in Dai Viet villages are 27 percentage points more likely to feel that this is the responsibility of the people (column 7). This may indicate a less severe free-rider problem, in which citizens recognize their own responsibility to improve village life. Dai Viet respondents are also more likely to be active in an interest group and are more likely to report that the people of the village 
decide which self-development projects will be implemented, rather than government heads (columns 8-9). The public opinion results are broadly robust to alternative bandwidths (Figure A-7) and to controlling for population, dropping Ho Chi Minh City, and dropping all provincial capitals (Tables A-23 through A-25).

Current data about civil society, local government, and public opinion are sparsely available for Vietnam, a communist country where officially civic engagement occurs through the Party and local government is managed by communist officials. As discussed in Section 2, informal institutions reflecting village structures remain active, but the state has been hesitant to acknowledge or collect information on these arrangements. Unlike many household surveys, VHLSS does not have a social capital module. Nevertheless, in the available data, we continue to see legacies of the historical state. The closest question to civic engagement systematically available in VHLSS asks about household expenditures on donations to charitable organizations, and we code an indicator for whether the household has donated to a charitable group. Table 10, column 1 documents that households in Dai Viet villages are 12 percentage points more likely to make charitable contributions (see also Figure 3, panel e).

Columns (2) through (6) consider human capital. Column (2) uses district-level information from provincial yearbooks (1999-2004) on the share of communes in each district with a secondary school, showing a greater prevalence in Dai Viet areas. In order to have enough districts for regression analysis, we need to extend the bandwidth to $100 \mathrm{~km}$, so this estimate should be interpreted with caution. We do not examine primary schools or health posts because access today is nearly universal. Columns (3) through (6) use individuallevel data from VHLSS on years of schooling. Column (3) reports the average effect for all individuals over 25, whereas columns (4) through (6) consider different cohorts separately. We focus on adult cohorts as they are likely to have completed schooling. The estimates are positive and statistically significant, documenting that individuals in areas historically under a strong state have an additional 0.9 years of schooling. This is shown graphically in Figure 3, panel f). While the absolute effect is roughly similar across cohorts, the effect is proportionally larger for older individuals, since the older cohort has only half the schooling of the younger cohort. The estimates are consistent with the historical results on access to schooling and suggest some convergence over time. The direct impacts of education today are large enough to explain about a third of the economic differences, using typical returns to education. Figure A-8 documents that the estimates are broadly robust to the choice of bandwidth. Tables A-26 through A-28 show that results remain similar when Ho Chi Minh City and Province are dropped and when provincial capitals are dropped. ${ }^{62}$

This study documents that the historical state exerts long-run impacts on collective

\footnotetext{
${ }^{62}$ The impact on the share of households that contribute to charity is no longer statistically significant when all of Ho Chi Minh Province is excluded, but the coefficient remains large and positive.
} 
action. There could be many mechanisms linking the historical state to economic outcomes, but we argue that it is difficult to tell a compelling story where this does not play a role. Figure A-11 shows that there is a strong relationship in the raw data between the civil society LCA and the economic LCA, as well as between the civil society LCA and the health care and education LCAs. Providing local public goods that promote development inherently requires working together. Villages that are richer might be able to afford to invest more in local collective action, creating a virtuous feedback loop that is sustained in the long-run.

We next consider some other potential mechanisms, starting with the Vietnam War. The war is unlikely to be an omitted variable. Our study region is in the same military corps region, with no reason to expect military strategy to change discontinuously at the boundary, and we find economic impacts of the historical state prior to the war. Moreover, Dell and Querubin (2016) do not find long-run effects of bombing - one of the most destructive features of the war - using the same data sources as this study, and Miguel and Roland (2011) likewise find no long-run impacts of bombing.

If the historical state impacted insurgency, the war could be a contributing mechanism, but Table 11 finds little evidence for major differences in conflict across the Dai Viet boundary, using a variety of detailed data drawn from the U.S. National Archives. Column (1) considers the security LCA, which combines the security questions available in HES. The coefficient is small in magnitude and statistically insignificant. Columns (2) through (7) examine representative individual outcomes that enter the LCA. Columns (2) and (3) do not find impacts on whether there are Viet Cong (VC) forces or a VC base nearby. Dai Viet villages are 6.5 percentage points more likely to have a $\mathrm{VC}$ village guerrilla squad, which consists entirely of locals who are part-time fighters (column 4). At the same time, they are less likely to have a VC main squad, which consists of regular forces from elsewhere (columns 5). VC supporters in Dai Viet villages appear better able to organize into a guerrilla squad, but the $\mathrm{VC}$ compensated this by sending more regular forces to former Khmer areas. Columns 6 and 7 do not find impacts on presence of the VC Infrastructure, which organized VC political activities, or on VC taxation.

HES likewise contains information on whether friendly (U.S. and South Vietnamese) forces operated nearby in the past month and whether friendly air or artillery strikes hit near populated areas (columns 8 and 9). While the coefficients are negative, neither is close to being statistically significant. We can likewise examine security using administrative data from the U.S. and South Vietnamese armed forces that track ground troop activity ("Situation Report Army", RG 218). There is not an impact on U.S. initiated attacks near the hamlet (column 10), but South Vietnamese initiated attacks are lower in Dai Viet villages (column 11). This is likely because South Vietnamese ground troops pursued VC main force squads. Finally, we consider data on South Vietnamese regional defense forces from the 
the "Territorial Forces Evaluation System" (RG 472) and the "Territorial Forces Activity Reporting System" (RG 330) and again do not find a discontinuity (column 12).

These results are broadly robust to widening the bandwidth, with security on the Dai Viet side tending to be better relative to the Khmer side as the bandwidth is extended towards 100 kilometers (Appendix Figure A-9). Results are robust to controlling for population, dropping Ho Chi Minh City, and dropping all provincial capitals (Tables A-29 to A-31).

Effects likewise do not appear to be driven by recent land inequality. Recall from Section 2 that there were almost no French estates near the 1698 boundary - nearly every village is a zero in these data - but we also examine agricultural and land outcomes more recently. The dependent variable in column (1) of Table 12 is an indicator equal to 1 if the household is engaged in agricultural production, taken from VHLSS. The estimates show that Dai Viet households are less likely to work in agriculture, consistent with the economic effects discussed earlier. Column (2) examines agricultural land size, in hectares, for agricultural households. Though some caution is warranted since this outcome is selected, the coefficient is small relative to the mean and statistically insignificant. This indicates that differences in average farm size are unlikely to drive the observed economic differences. In Column (3), the dependent variable is an indicator equal to 1 if the individual works in a manufacturing industry, again from VHLSS. We restrict analysis to prime-age men, in order to avoid conflating effects with selection into the labor force. The point estimate is small and statistically insignificant, suggesting that households in Dai Viet areas are more likely to move out of agriculture into owner-operated businesses and services. We also examined manufacturing in detail using the 2012 Enterprise Census and did not find major differences in the distribution of employment across manufacturing sectors (results available upon request).

However, the VHLSS commune questionnaire does reveal that a lower share of land is formally titled in Dai Viet villages. Columns (4) through (6) estimate equation (1) using the fraction of area of different types of land in each commune with a land use certificate as the dependent variable. The estimates show a lower prevalence of land-use certificates in areas historically under a strong state, for annual, perennial, and residential land. If property rights are de facto secure for villagers due to strong communal enforcement, they may demand fewer formal titles, or there may be social pressure to participate in community norms rather than formal titling.

On a related note, column (7) examines whether the use of formal financial services is more or less widespread in historically Dai Viet areas. Results are again consistent with less active impersonal markets. Households in Dai Viet villages are 10 percentage points less likely to make interest expenses on formal financial instruments, despite being wealthier. This contrasts to Italy, where Guiso et al. (2004) find that in high-social-capital areas, households are more likely to use checks, invest less in cash and more in stock, have higher 
access to institutional credit, and make less use of informal credit. Market institutions arrived in Vietnam recently, and may still be less effective than non-market institutions in places where social capital is high, and hence non-market arrangements work relatively well. Finally column (8) considers informal sector employment, limiting to prime age males. In contrast to the land titling and financial sector results, informal sector employment is lower in Dai Viet villages. This is largely driven by the fact that there is less agriculture, which makes up the bulk of the informal sector. These results are broadly robust to the choice of bandwidth (Figure A-10), with the impact on land size becoming negative and significant when wider bandwidths are used. The results are also robust to excluding Ho Chi Minh City and Province and provincial capitals (Tables A-32 to A-34).

Vietnam has become increasingly globalized in recent years, and an additional hypothesis is that Dai Viet villages are richer in part because they have been better at attracting foreign investment. For example, a review by Nielsen et al. (2017) suggests that places with higher human capital are often better able to attract FDI. However, using data from the 2011 Enterprise Census, Table A-35 shows that foreign sector employment is actually lower in Dai Viet villages. ${ }^{63}$ This is consistent with historically tight-knit villages being more closed towards outsiders, although other explanations could also be at play. In any case, a greater prevalence of FDI in Dai Viet villages is unlikely to drive the results.

\section{Conclusion}

Using a regression discontinuity design across the Dai Viet-Khmer boundary, this study documents that areas historically under a strong state have higher living standards today and better economic outcomes over the past 150 years. Rich historical data reveal that in villages with a strong historical state, citizens have been better able to organize for public goods and redistribution through civil society and local government.

The strong historical state plausibly crowded in village-level collective action, and these norms persisted long after the original state disappeared. While care must be taken with external validity, this study provides support for the theory that the existence of a strong historical state in East Asia - which encouraged local collective action - played a central role in the 20th century divergence between this region and much of the developing world.

\footnotetext{
${ }^{63}$ The Enterprise Census includes formal firms and identifies the location of the headquarters.
} 


\section{References}

Acemoglu, D., D. Cantoni, S. Johnson, And J. A. Robinson (2011): "The Consequences of Radical Reform: The French Revolution," American Economic Review, 101, 3286-3307.

Acemoglu, D., C. Garcia-Jimeno, and J. A. Robinson (2015): "State Capacity and Economic Development: A Network Approach," The American Economic Review, 105, 2364-2409.

Acemoglu, D., S. Johnson, And J. A. Robinson (2001): "The Colonial Origins of Comparative Development: An Empirical Investigation," The American Economic Review, 91, 1369-1401.

(2002): "Reversal of Fortune: Geography and Institutions in the Making of the Modern World Income Distribution," The Quarterly Journal of Economics, 117, 1231-1294.

Acemoglu, D., T. Reed, And J. A. Robinson (2014): "Chiefs: Economic Development and Elite Control of Civil Society in Sierra Leone," Journal of Political Economy, 122, 319-368.

Acharya, A. (2013): Civilizations in Embrace: The Spread of Ideas and the Transformation of Power: India and Southeast Asia in the Classical Age, vol. 2, Singapore: Institute of Southeast Asian Studies.

Alesina, A., R. Baqir, And W. Easterly (1999): "Public Goods and Ethnic Divisions," The Quarterly Journal of Economics, 114, 1243-1284.

Alesina, A. And N. Fuchs-Schündeln (2007): "Goodbye Lenin (Or Not?): The Effect of Communism on People," American Economic Review, 97, 1507-1528.

Alesina, A. And P. Giuliano (2015): "Culture and Institutions," Journal of Economic Literature, 53, 898944.

Alesina, A., P. Giuliano, And N. Nunn (2013): "On the Origins of Gender Roles: Women and the Plough," The Quarterly Journal of Economics, 128, 469-530.

Alesina, A. And E. La Ferrara (2005): "Ethnic Diversity and Economic Performance," Journal of Economic Literature, 43, 762-800.

Barnes, G. L. (2007): State Formation in Japan: Emergence of a 4th-century Ruling Elite, London, England and New York, New York: Routledge, Taylor \& Francis.

Bazzi, S. And M. Gudgeon (2016): "Local Government Proliferation, Diversity, and Conflict," Working paper, Boston University, https://www.bu.edu/econ/files/2016/04/BazziGudgeon_Manuscript.pdf.

Becker, S. O., K. Boeckh, C. Hainz, and L. Woessmann (2016): "The Empire Is Dead, Long Live the Empire! Long-Run Persistence of Trust and Corruption in the Bureaucracy," The Economic Journal, 126, $40-74$.

Besley, T. (1995): "Nonmarket Institutions for Credit and Risk Sharing in Low-Income Countries," The Journal of Economic Perspectives, 9, 115-127.

Bоотн, A. (2007): "Night Watchman, Extractive, or Developmental States? Some Evidence from Late Colonial South-East Asia," The Economic History Review, 60, 241-266.

Bredo, W. (1968): Land Reform in Vietnam, Stanford Research Institute.

Briggs, L. P. (1947): "A Sketch of Cambodian History," The Far Eastern Quarterly, 6, 345.

Bukowski, P. (2016): "How History Matters for Student Performance. Lessons from the Partitions of Poland," Working paper, Central European University, http://www.personal.ceu.hu/staff/repec/pdf/2015_3. pdf.

Chandler, D. P. (1983): A History of Cambodia, Westview Press. 
Chutintaranond, S. (1990): "Mandala", "Segmentary State" and Politics of Centralisation in Medieval Ayudhya," Journal of the Siam Society, 78, 89-100.

CEE DÈs, G. (1966): The Making of South East Asia, University of California Press.

Cotter, M. G. (1968): "Towards a Social History of the Vietnamese Southward Movement," Journal of Southeast Asian History, 9, 12-24.

Cotterell, A. (2014): A History of Southeast Asia, West Sussex, U.K.: Wiley Blackwell.

Deaton, A. (1997): The Analysis of Household Surveys: A Microeconometric Approach to Development Policy, World Bank.

Dell, M. (2010): "The Persistent Effects of Peru's Mining Mita," Econometrica, 78, 1863-1903.

Dell, M. And P. Querubin (2016): "Nation Building Through Foreign Intervention: Evidence From Discontinuities in Military Strategies," Working Paper 22395, National Bureau of Economic Research.

Demsetz, H. (1967): "Toward a Theory of Property Rights," American Economic Review, 57, 347-359.

Dùc, T. H. And N. TaO (1972): Gia Dinh Thành Thông Chí, Nha Ván hóa, Phù Quóc-vu-khanh D̀ac-trách Văn-hóa.

Easterly, W. And R. Levine (1997): "Africa's Growth Tragedy: Policies and Ethnic Divisions," The Quarterly Journal of Economics, 112, 1203-1250.

Ebihara, M. (1984): "Social Organization in Sixteenth and Seventeenth Century Cambodia," Journal of Southeast Asian Studies, 15, 280-295.

Engelbert, T. (1994): "The Khmer in Southern Vietnam-Cambodians or Vietnamese?" Nationalism and Ethnicity in Southeast Asia, 1, 155-196.

Evans, P. B. (1995): Embedded Autonomy: States and Industrial Transformation, Princeton University Press.

Fernández, R. And A. Fogli (2009): "Culture: An Empirical Investigation of Beliefs, Work, and Fertility," American Economic Journal: Macroeconomics, 1, 146-177.

Foster, G. M. (1965): "Peasant Society and the Image of Limited Good," American Anthropologist, 67, 293-315.

Funuyama, F. (1995): Trust: The Social Virtues and the Creation of Prosperity, Free Press.

Gelman, A. And G. Imbens (2014): "Why High-order Polynomials Should not be Used in Regression Discontinuity Designs," Working Paper 20405, National Bureau of Economic Research.

Gennaioli, N. And I. Rainer (2007): "The Modern Impact of Precolonial Centralization in Africa," Journal of Economic Growth, 12, 185-234.

Giuliano, P. (2007): "Living Arrangements in Western Europe: Does Cultural Origin Matter?" Journal of the European Economic Association, 5, 927-952.

Gouldner, A. W. (1980): The Two Marxisms: Contradictions and Anomalies in the Development of Theory, Critical Social Studies, Macmillan.

GreIF, A. (1994): "Cultural Beliefs and the Organization of Society: A Historical and Theoretical Reflection on Collectivist and Individualist Societies," Journal of Political Economy, 102, 912-950.

Greif, A. And G. Tabellini (2010): "Cultural and Institutional Bifurcation: China and Europe Compared," American Economic Review, 100, 135-140. 
Grosjean, P. (2011): "The Weight of History on European Cultural Integration: A Gravity Approach," American Economic Review, 101, 504-508.

(2014): "A History of Violence: The Culture of Honor and Homicide in the US South," Journal of the European Economic Association, 12, 1285-1316.

Guiso, L., P. Sapienza, And L. Zingales (2004): "The Role of Social Capital in Financial Development," American Economic Review, 94, 526-556.

_ (2008): "Alfred Marshall Lecture: Social Capital as Good Culture," Journal of the European Economic Association, 6, 295-320.

- (2016): "Long-Term Persistence," Journal of the European Economic Association, 14, 1401-1436.

Haines, D. (1984): "Reflections of Kinship and Society Under Vietnam's Le Dynasty," Journal of Southeast Asian Studies, 15, 307-314.

Hall, D. (1968): A History of South-East Asia, Macmillan and Company, Limited and St. Martin's Press.

- (1973): "The Integrity of Southeast Asian History," Journal of Southeast Asian Studies, 4, 159-168.

Hall, K. R. (2011): A History of Early Southeast Asia: Maritime Trade and Social Development, 100-500, Rowman \& Littlefield Publishers.

Harding, A. (2001): "Comparative Law and Legal Transplantation in South East Asia: Making Sense of the 'Nomic Din'," in Adapting legal cultures, ed. by D. Nelken and J. Feest, Hart Publishing.

Hayami, Y. (1980): "Economic Approach to Village Community and Institutions," Journal of Rural Development, 3, 27-49.

Hooker, M. B. (1978a): A Concise Legal History of South-East Asia, Clarendon Press and Oxford University Press.

_ (1978b): "The Indian-Derived Law Texts of Southeast Asia," The Journal of Asian Studies, 37, 201-219.

Hoover, D. R. (2000): "The Sources of Social Capital Reconsidered: Voluntary Associations, Advocacy and the State," in Social Structures, Social Capital, and Personal Freedom, ed. by D. McConkey and P. Lawler, Praeger.

Jansen, M. B. (2000): China in the Tokugawa World, Harvard University Press.

Kang, D. C. (2010): "Hierarchy and Legitimacy in International Systems: The Tribute System in Early Modern East Asia," Security Studies, 19, 591-622.

Kang, D. C. And V. D. Cha (2010): East Asia Before the West. Five Centuries of Trade and Tribute, Columbia University Press.

Kerkvliet, B. J. And D. G. Marr (2004): Beyond Hanoi: Local Government in Vietnam, Institute of Southeast Asian Studies / Nordic Institute of Asian Studies.

Kulke, H. (1986): "Early and the Imperial Kingdoms in Southeast Asian History," in Southeast Asia in the 9th to 14 th Century, ed. by D. G. Marr and A. C. Milner, Institute of Southeast Asian Studies and Australian National University, Research School of Pacific Studies.

Lehning, P. B. (1998): "Towards a Multicultural Civil Society: The Role of Social Capital and Democratic Citizenship," Government and Opposition, 33, 221-242.

Lewis, M. E. (2009): China's Cosmopolitan Empire, Belknap Press and Harvard University Press.

- (2011): China Between Empires: The Northern and Southern Dynasties, Harvard University Press. 
LI, T. (1998): Nguyen Cochinchina: Southern Vietnam in the Seventeenth and Eighteenth Centuries, SEAP Publications.

Lieberman, V. (1987): "Reinterpreting Burmese History," Comparative Studies in Society and History, 29, 162.

(1993): "Local Integration and Eurasian Analogies: Structuring Southeast Asian History, c. 1350-c. 1830," Modern Asian Studies, 27, 475-572.

(2003): Strange Parallels: Volume 1, Integration on the Mainland: Southeast Asia in Global Context, c.800-1830, Cambridge University Press.

Liu, H. (2007): "Influence of China's Imperial Examinations on Japan, Korea and Vietnam," Frontiers of History in China, 2, 493-512.

Lowes, S., N. Nunn, J. A. Robinson, And J. Weigel (2015): "The Evolution of Culture and Institutions: Evidence from the Kuba Kingdom," Working Paper 21798, National Bureau of Economic Research.

Luttmer, E. F. P. And M. Singhal (2011): "Culture, Context, and the Taste for Redistribution," American Economic Journal: Economic Policy, 3, 157-79.

Mabbett, I. W. (1977a): "The 'Indianization' of Southeast Asia : Reflections on the Historical Sources," Journal of Southeast Asian Studies, 8, 143-161.

_ (1977b): "Varas in Angkor and the Indian Caste System," The Journal of Asian Studies, 36, 429-442. (1978): "Kingship in Angkor," Journal of the Siam Society, 66, 1-58.

Mabbett, I. W. And D. P. Chandler (1995): The Khmers, Oxford, U.K. and Cambridge, Massachusetts: Blackwell Publishers.

Marr, D. G. (2004): "A Brief History of Local Government in Vietnam," in Beyond Hanoi: Local Government in Vietnam, ed. by B. J. T. Kerkvliet and D. G. Marr, Institute of Southeast Asian Studies / Nordic Institute of Asian Studies.

Martinez-Bravo, M., G. Padró i Miquel, N. Qian, and Y. Yao (2012): "Elections in China," Working Paper 18101, National Bureau of Economic Research.

McHale, S. (2013): "Ethnicity, Violence, and Khmer-Vietnamese Relations: The Significance of the Lower Mekong Delta, 1757-1954," The Journal of Asian Studies, 72, 367-390.

Meyer, K. E. And H. V. Nguyen (2005): "Foreign Investment Strategies and Sub-National Institutions in Emerging Markets: Evidence from Vietnam," Journal of Management Studies, 42, 63-93.

Michalopoulos, S. and E. Papaionnnou (2013): "Pre-Colonial Ethnic Institutions and Contemporary African Development," Econometrica, 81, 113-152.

Miguel, E. And G. Roland (2011): "The Long-Run Impact of Bombing Vietnam," Journal of Development Economics, 96, 1-15.

Montalvo, J. And M. Reynal-Querol (2005a): "Ethnic Diversity and Economic Development," Journal of Development Economics, 76, 293-323. 796-816.

Mus, P. (1949): "The Role of the Village in Vietnamese Politics," Pacific Affairs, 22, 265-272.

Nguyen, A. T. (1985): "The Vietnamese Monarchy under French Colonial Rule 1884-1945," Modern Asian Studies, 19, 147-162. 
(2003): "Village Versus State: The Evolution of State-Local Relations in Vietnam Until 1945," South East Asian Studies, 41, 101-123.

Nguyen, T. D. (1999): The Mekong River and the Struggle for Indochina: Water, War, and Peace, Praeger.

Nielsen, B. B., C. G. Asmussen, and C. D. Weatherall (2017): "The Location Choice of Foreign Direct Investments: Empirical Evidence and Methodological Challenges," Journal of World Business, 52, 62 - 82.

Nunn, N. (2008): "The Long-Term Effects of Africa's Slave Trades," The Quarterly Journal of Economics, $123,139-176$.

Nunn, N. and L. Wantchekon (2011): "The Slave Trade and the Origins of Mistrust in Africa," American Economic Review, 101, 3221-3252.

Osborne, M. (1966): "History and Kingship in Contemporary Cambodia," Journal of Southeast Asian History, $7,1-14$.

Osborne, M. E. (1969): The French presence in Cochinchina and Cambodia: Rule and Response (1859-1905), Cornell University Press.

Oto-Peralías, D. and D. Romero-Ávila (2014): "The Distribution of Legal Traditions Around the World: A Contribution to the Legal-Origins Theory," Journal of Law and Economics, 57, 561-628.

Padro i Miquel, G., N. Qian, Y. Xu, and Y. Yao (2015): "Making Democracy Work: Culture, Social Capital and Elections in China," Working Paper 21058, National Bureau of Economic Research.

Palais, J. B. (1996): Confucian Statecraft and Korean Institutions: Yu Hyongwon and the Late Choson Dynasty, Seattle, Washington: University of Washington Press.

Parthesius, R. (2010): Dutch Ships in Tropical Waters: The Development of the Dutch East India Company (VOC) Shipping Network in Asia 1595-1660, Amsterdam studies in the Dutch golden age, Amsterdam University Press.

Pastor, J. (1997): "Land and Economy in Ancient Palestine," Journal of Southeast Asian Studies, 1, 306.

Popkin, S. L. (1976): "Corporatism and Colonialism: The Political Economy of Rural Change in Vietnam," Comparative Politics, 431-464.

(1979): The Rational Peasant: The Political Economy of Rural Society in Vietnam.

Porter, G. (1993): Vietnam: The Politics of Bureaucratic Socialism, Cornell University Press.

Putnam, R. D., R. Leonard, And R. Y. Nanetti (1994): Making democracy work: Civic traditions in modern Italy, Princeton University Press.

QIAN, N. (2012): "Village Governance in China," in The Oxford Companion to the Economics of China, Oxford University Press, USA.

Roland, G. (2012): "The Long-Run Weight of Communism or the Weight of Long-Run History?" in Economies in Transition, Springer, 153-171.

SahaI, S. (1970): Les Institutions Politiques et l'Organisation Administrative du Cambodge Ancien (VIe-XIIIe siècles), 75, Paris: École française d'Extréme-Orient Publications.

Satyanath, S., N. Voigtlaender, and H.-J. Voth (2013): "Bowling for Fascism: Social Capital and the Rise of the Nazi Party," Working Paper 19201, National Bureau of Economic Research.

Scott, J. C. (1977): The Moral Economy of the Peasant: Rebellion and Subsistence in Southeast Asia, Yale University Press.

Skocpol, T. (1995): Protecting Soldiers and Mothers, Harvard University Press. 
Spolaore, E. And R. Wacziarg (2013): "How Deep Are the Roots of Economic Development?" Journal of Economic Literature, 51, 325-369.

Su Quan Trieu Nguyen, Q. And T. D. Pham (1992): Dai Nam Nhat Thong Chi, Nha Xuat Ban Thuan Hoa.

Tabellini, G. (2008): "Presidential Address: Institutions and Culture," Journal of the European Economic Association, 6, 255-294.

(2010): "Culture and Institutions: Economic Development in the Regions of Europe," Journal of the European Economic Association, 8, 677-716.

Tambiah, S. J. (1977): "The Galactic Polity: The Structure of Traditional Kingdoms in Southeast Asia," Annals of the New York Academy of Sciences, 293, 69-97.

- (2013): "The Galactic Polity in Southeast Asia," HAU: Journal of Ethnographic Theory, 3, 503-534.

Tarling, N. (1999): The Cambridge History of Southeast Asia, Cambridge University Press.

TAYlor, K. W. (2013): A History of the Vietnamese, Cambridge Concise Histories, Cambridge University Press.

Thien, D. (2003): Vietnamese Supernaturalism: Views from the Southern Region, Taylor \& Francis.

Vickery, M. (1996): "Mak Phœun : Histoire du Cambodge de la fin du XVIe au début du XVIIIe siècle," Bulletin de l'Ecole française d'Extrême-Orient, 83, 405-415.

Voigtränder, N. And H.-J. Voth (2012): "Persecution Perpetuated: The Medieval Origins of Anti-Semitic Violence in Nazi Germany," The Quarterly Journal of Economics, 127, 1339-1392.

Wade, R. H. (1994): Village Republics: Economic Conditions for Collective Action in South India, International Center for Self-Governance, San Francisco: Institute for Contemporary Studies.

Whitmore, J. K. (1979): "Merit Subjects: China, Korea, Vietnam," Ming Studies, 1979, 42-51.

Wolf, E. R. (1969): Peasant Wars of the Twentieth Century, University of Oklahoma Press.

Wolters, O. (1999): History, Culture and Region in Southeast Asian Perspectives, Southeast Asia Program Publications, Cornell University.

Woodside, A. B. (1971): Vietnam and the Chinese Model: A Comparative Study of Vietnamese and Chinese Government in the First Half of the Nineteenth Century, Harvard University Asia Center.

(1984): "Medieval Vietnam and Cambodia: A Comparative Comment," Journal of Southeast Asian Studies, 15, 315-319. Press.

(2006): Lost Modernities : China, Vietnam, Korea and the Hazards of World, Harvard University

Wook, C. B. (2004): Southern Vietnam Under the Reign of Minh Mang (1820-1841): Central Policies and Local Response, SEAP Publications.

Woolcock, M. And D. NArayan (2000): "Social Capital: Implications for Development Theory, Research, and Policy," World Bank Research Observer, 15, 225-49.

YU, I. (2001): "The Changing Nature of the Red River Delta Villages During the Lê Period (1428-1788)," Journal of Southeast Asian Studies, 32, 151-172.

Zotтoli, B. A. (2011): "Reconceptualizing Southern Vietnamese History Form the 15th to 18th Centuries: Competition Along the Coasts Form Guangdong to Cambodia," Ph.D Dissertation, The University of Michigan, https://deepblue.lib.umich.edu/handle/2027.42/89821. 
Figure 1: Dai Viet Historical Boundaries

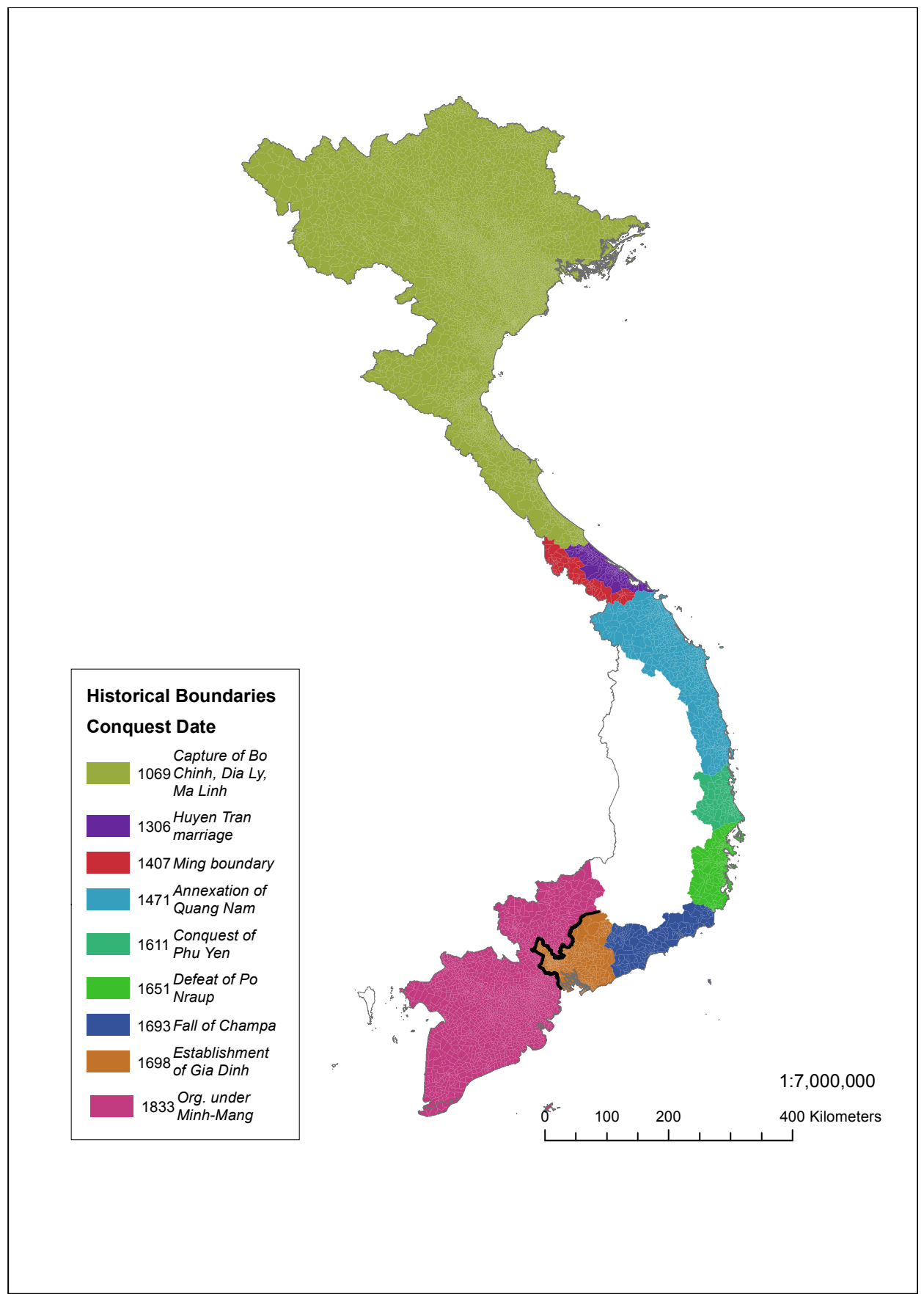

Sources: Dùc and Tao (1972); Su Quan Trieu Nguyen and Pham (1992). 
Figure 2: Robustness of Household Consumption Estimates

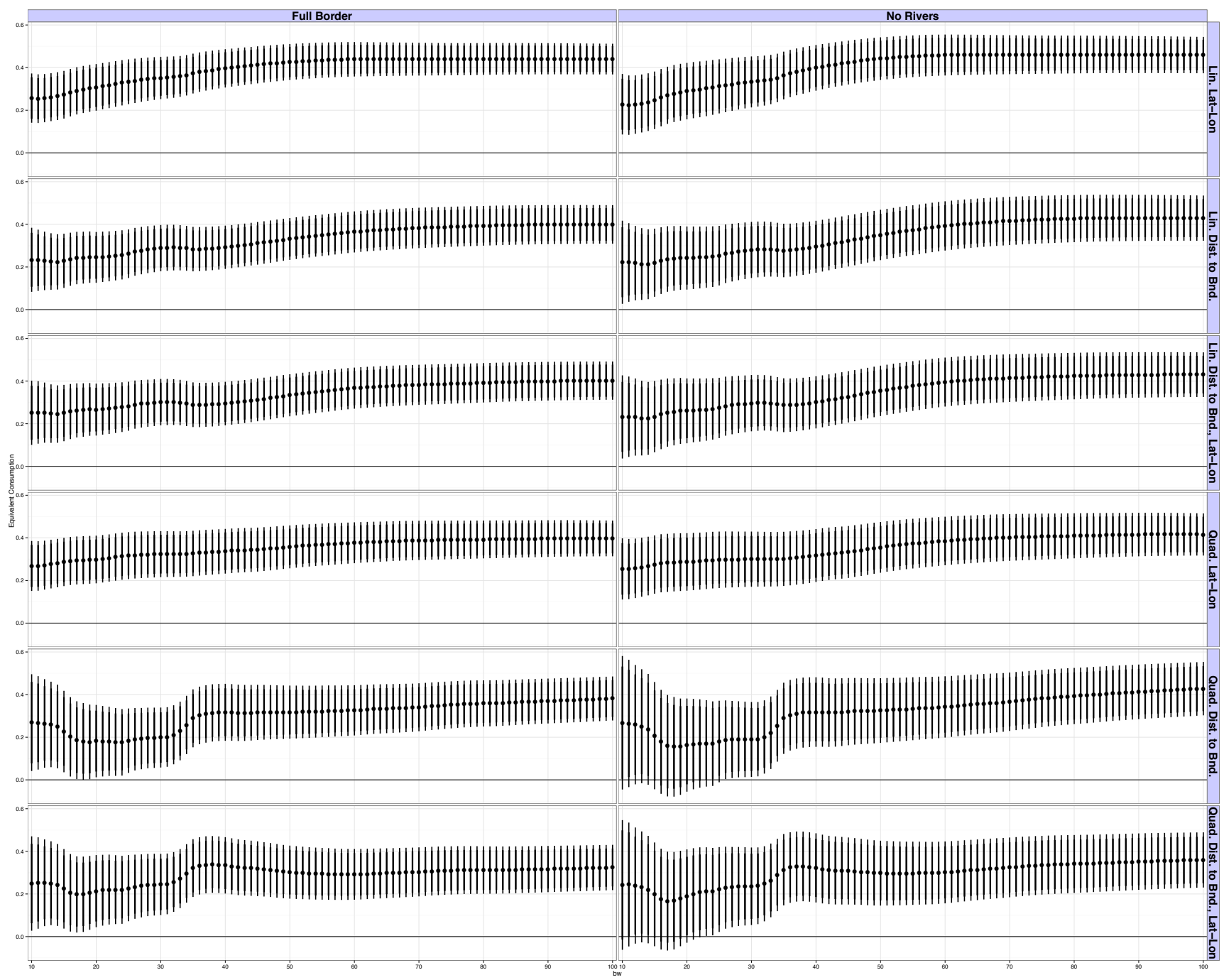

Notes: Each sub-figure plots the point estimates of $\gamma$ (vertical axis) from equation (1) for different bandwidth values between 10-100 kilometers in $1 \mathrm{~km}$ increments (horizontal axis). Thin lines stemming from the point estimates show $95 \%$ confidence intervals while the slightly thicker lines show $90 \%$ confidence intervals. The panels in different rows correspond to different polynomial functions for geographic location. The estimates in the first column are based on the full border while those in the second column exclude households closest to boundary segments that coincide with a river. 
Figure 3: RD graphs

(a) Household Consumption

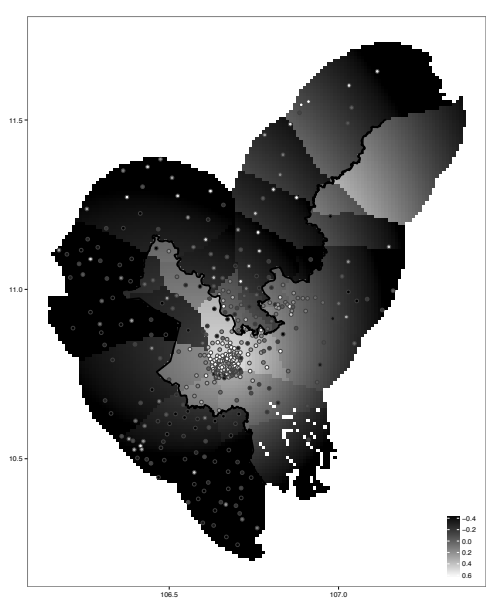

(c) Civil Society LCA Index

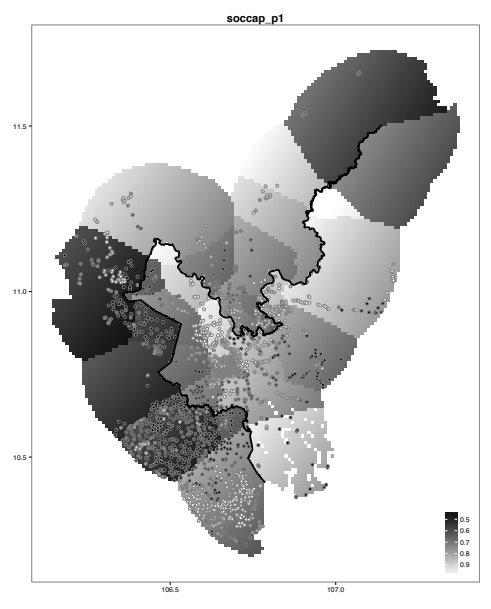

(e) Household Donates to Charity

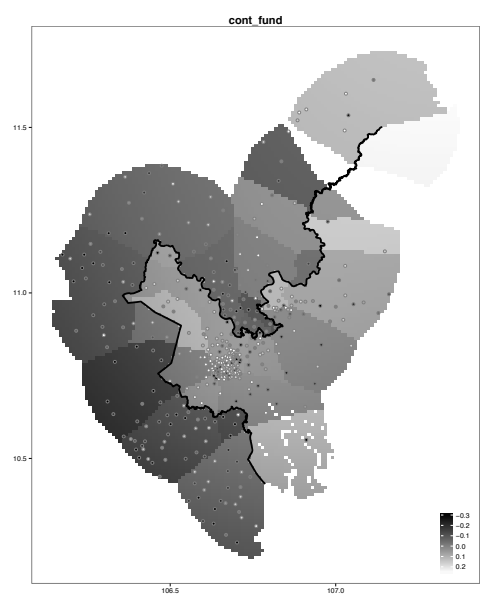

(b) Economic LCA Index

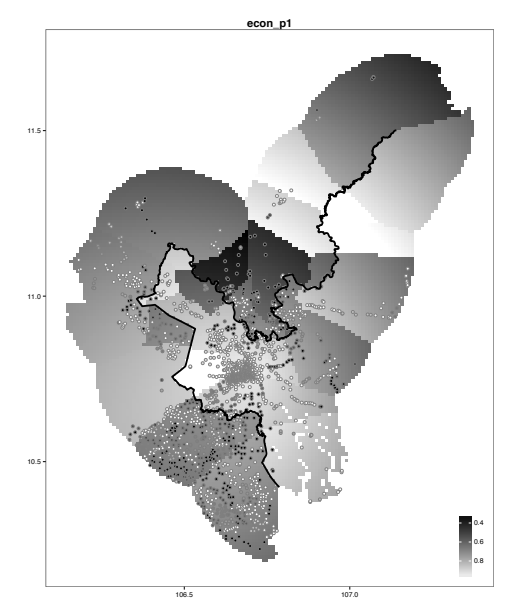

(d) Public Health Care Provision LCA Index

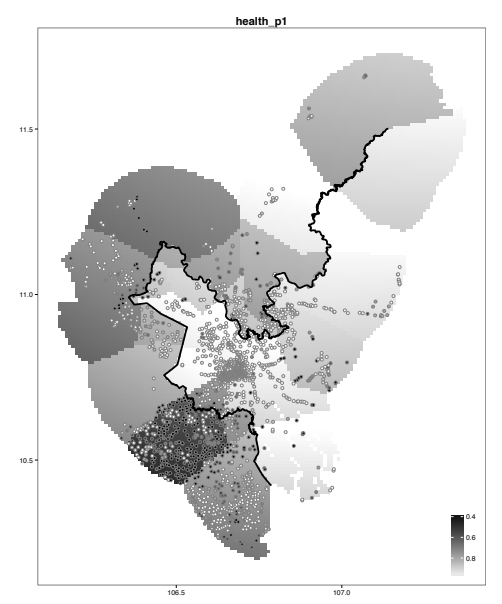

(f) Years of Schooling

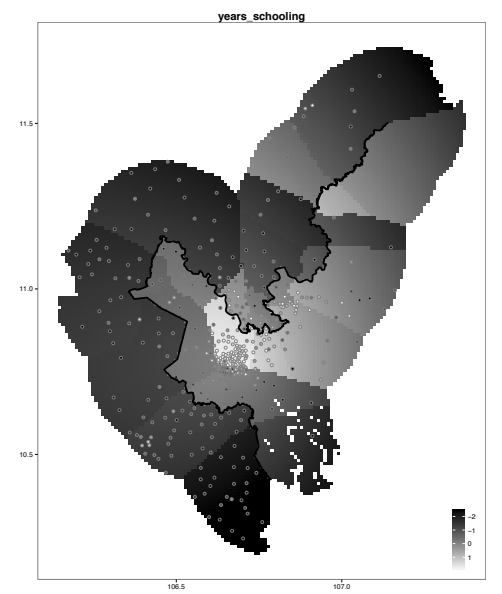

Notes: Longitude is on the $\mathrm{x}$-axis, latitude is on the $\mathrm{y}$-axis, and the data value is shown using an evenly-spaced monochromatic color scale. The background shows predicted values, for a finely spaced grid of longitude-latitude coordinates, from a regression of the outcome variable under consideration using equation (1). 
Table 1: Comparing Dai Viet and Khmer Kingdoms in Precolonial Vietnam

\begin{tabular}{|l|l|}
\hline Dai Viet & Khmer \\
\hline $\begin{array}{l}\text { Colonial outpost of China (111 } \\
\text { BCE-939 CE) }\end{array}$ & Indic patron-client state ${ }^{a}$ \\
$\begin{array}{l}\text { Maintained bureaucratic Chinese } \\
\text { government system since inde- } \\
\text { pendence }\end{array}$ & $\begin{array}{l}\text { Accelerated decline after invasion } \\
\text { by Siam (1430); weak control of } \\
\text { periphery }\end{array}$ \\
$\begin{array}{l}\text { Centralized state; impersonal } \\
\text { centralized bureaucracy under } \\
\text { dynastic court; uniform territo- } \\
\text { rial administration }{ }^{d}\end{array}$ & $\begin{array}{l}\text { Decentralized state; personalis- } \\
\text { tic rule through court; semi- } \\
\text { independent provincial rule }\end{array}$ \\
$\begin{array}{l}\text { Institutionalized role of village } \\
\text { chiefs \& village councils (elected } \\
\text { since 1461) }\end{array}$ & $\begin{array}{l}\text { Personalistic political appoint- } \\
\text { ments \& land distribution }{ }^{g}\end{array}$ \\
$\begin{array}{l}\text { Bureaucratic control of local tax- } \\
\text { ation, military recruitment }\end{array}$ & $\begin{array}{l}\text { Temple-based public finance sys- } \\
\text { tem }\end{array}$ \\
\hline
\end{tabular}

${ }^{a}$ Lieberman, 2003

${ }^{b}$ Woodside, 1971

${ }^{c}$ Coedes, 1966; Tarling, 1999

${ }^{d}$ Lieberman, 2003

${ }^{e}$ Woodside, 1971; Tarling, 1999

${ }^{f} \mathrm{Yu}, 2001$

${ }^{g}$ Osborne, 1969; Chandler, 1983

${ }^{h}$ Woodside, 1971; Yu, 2001

${ }^{i}$ Tarling, 1999; Hall, 2010 
Table 2: Balance Checks

\begin{tabular}{lccccccc}
\hline \multicolumn{7}{c}{ Dependent variable is: } \\
& $\begin{array}{c}\text { Elev. } \\
(1)\end{array}$ & $\begin{array}{c}\text { Slope } \\
(2)\end{array}$ & $\begin{array}{c}\text { Temp. } \\
(3)\end{array}$ & $\begin{array}{c}\text { Precip. } \\
(4)\end{array}$ & $\begin{array}{c}\text { Rice Suit. } \\
(5)\end{array}$ & $\begin{array}{c}\text { Flow Accum. } \\
(6)\end{array}$ & $\begin{array}{c}\text { Km Rivers } \\
(7)\end{array}$ \\
\hline Dai Viet & -1.562 & 0.356 & 0.052 & 2.084 & 0.371 & -1.758 & -1.195 \\
& $(10.027)$ & $(0.596)$ & $(0.053)$ & $(1.206)$ & $(0.611)$ & $(1.483)$ & $(2.666)$ \\
Obs & 120 & 120 & 120 & 120 & 119 & 120 & 120 \\
Clusters & 120 & 120 & 120 & 120 & 119 & 120 & 120 \\
Mean & 51.39 & 2.59 & 26.65 & 168.34 & 27.28 & 0.66 & 17.01 \\
\hline
\end{tabular}

The unit of analysis is the grid cell. All regressions include a linear RD polynomial in latitude and longitude, a control for distance to Ho Chi Minh City, and boundary segment FE. Robust standard errors are reported in parentheses.

Table 3: Contemporary Household Consumption

\begin{tabular}{|c|c|c|c|c|c|c|c|c|c|c|c|c|}
\hline & \multicolumn{12}{|c|}{ Dependent variable is log household expenditure. Specification is: } \\
\hline & & Dist. & Lat-Lon & No & No & No & & & Consist. & Trim & 25 to & \\
\hline & Lat-Lon & Bnd. & \& Dist. & Urban & $\mathrm{HCM}$ & Prov. & No & Only & Prov. & For & 100 & All \\
\hline & & Polynomial & & HCMC & Prov. & Cap. & River & Bnd. & $\mathrm{FE}$ & Migr. & $\mathrm{Km}$ & SVN \\
\hline & (1) & $(2)$ & (3) & (4) & (5) & $(6)$ & (7) & (8) & (9) & (10) & (11) & $(12)$ \\
\hline \multirow[t]{2}{*}{ Dai Viet } & 0.331 & 0.259 & 0.280 & 0.344 & 0.322 & 0.329 & 0.311 & 0.340 & 0.405 & 0.281 & 0.329 & 0.351 \\
\hline & $(0.054)$ & $(0.059)$ & $(0.059)$ & $(0.055)$ & $(0.076)$ & $(0.059)$ & $(0.065)$ & $(0.084)$ & $(0.063)$ & $(0.050)$ & $(0.085)$ & $(0.026)$ \\
\hline Ob: & 4,319 & 4,319 & 4,319 & 3,483 & 2,565 & 2,866 & 3,597 & 722 & 4,319 & 4,240 & 6,789 & 25,617 \\
\hline Clusters & 450 & 450 & 450 & 362 & 258 & 312 & 374 & 76 & 450 & 450 & 670 & 2581 \\
\hline
\end{tabular}

The unit of analysis is the household. Columns (1) and (3) through (11) include a linear polynomial in latitude and longitude, and columns (2) and (3) include a linear polynomial in distance to the boundary. All columns include a control for distance to Ho Chi Minh City, demographic controls for the number of infants, children, and adults in the household, and year fixed effects. Columns (1) through (11) include boundary segment fixed effects, and column (9) includes consistent province fixed effects. Robust standard errors, clustered at the village level, are reported in parentheses. 
Table 4: Economic Outcomes: Colonial Period

\begin{tabular}{lcccccccc}
\hline & \multicolumn{1}{c}{ Dependent variable is: } \\
\hline & Telegraph & Military & Rail/Road & Motor Road & Rail & Paved & Rail \\
& \multicolumn{2}{c}{ Density } & Post & Density & Density & Density & Road Dens. & Density \\
& 1878 & 1901 & 1878 & 1878 & 1910 & 1910 & 1926 & 1926 \\
& $(1)$ & $(2)$ & $(3)$ & $(4)$ & $(5)$ & $(6)$ & $(7)$ & $(8)$ \\
\hline Dai Viet & 0.013 & 0.061 & -0.055 & -0.011 & 0.058 & 0.036 & 0.121 & 0.007 \\
& $(0.006)$ & $(0.032)$ & $(0.025)$ & $(0.031)$ & $(0.037)$ & $(0.021)$ & $(0.043)$ & $(0.016)$ \\
Obs & 691 & 691 & 691 & 691 & 691 & 691 & 691 & 691 \\
Clusters & 691 & 691 & 691 & 691 & 691 & 691 & 691 & 691 \\
Mean & 0.01 & 0.17 & 0.03 & 0.19 & 0.42 & 0.09 & 0.43 & 0.06 \\
\hline
\end{tabular}

The unit of analysis is the village. All regressions include a linear RD polynomial in latitude and longitude, a control for distance to Ho Chi Minh City, and boundary segment fixed effects. Robust standard errors are reported in parentheses.

Table 5: Economic Outcomes: South Vietnamese Period

\begin{tabular}{lccccccccc}
\hline & \multicolumn{10}{c}{ Dependent variable is: } \\
\hline & Log & & Non-rice & Manuf. & Surplus & Households & $\%$ HH & Land \\
& Family & Econ & Food & Goods & Goods & Require & Access & Unfarmed & Pop \\
& Income & LCA & Avail. & Avail. & Produced & Assist. & Vehic. & Bad Sec. & $\begin{array}{c}\text { Growth } \\
(9)\end{array}$ \\
& $(1)$ & $(2)$ & $(3)$ & $(4)$ & $(5)$ & $(6)$ & $(7)$ & $(8)$ & $(9)$ \\
\hline Dai Viet & 0.156 & 0.163 & 0.279 & 0.196 & 0.184 & -0.075 & 0.143 & 0.009 & -0.004 \\
& $(0.041)$ & $(0.055)$ & $(0.060)$ & $(0.065)$ & $(0.052)$ & $(0.038)$ & $(0.020)$ & $(0.047)$ & $(0.006)$ \\
Obs & 5,926 & 2,285 & 388 & 388 & 388 & 2,330 & 2,332 & 330 & 2,276 \\
Clusters & 172 & 392 & 388 & 388 & 388 & 397 & 396 & 330 & 396 \\
Mean & 9.72 & 0.82 & 0.71 & 0.63 & 0.44 & 0.61 & 0.34 & 0.26 & 0.01 \\
\hline
\end{tabular}

The unit of analysis is the household, hamlet, or village. All regressions include a linear RD polynomial in latitude and longitude, a control for distance to Ho Chi Minh City, and boundary segment fixed effects. Robust standard errors, clustered at the village level, are reported in parentheses. 
Table 6: Civil Society

\begin{tabular}{|c|c|c|c|c|c|c|c|c|c|c|c|c|}
\hline & \multicolumn{12}{|c|}{ Dependent variable is: } \\
\hline & Civil & \multirow{2}{*}{\multicolumn{2}{|c|}{$\begin{array}{l}\text { \% Households } \\
\text { Particpate in }\end{array}$}} & \multirow{4}{*}{$\begin{array}{c}\% \mathrm{HH} \\
\text { Active } \\
\text { in PSDF } \\
(4)\end{array}$} & \multirow{4}{*}{$\begin{array}{c}\text { Self-Dev. } \\
\text { Project } \\
\text { Underway } \\
(5)\end{array}$} & \multirow{4}{*}{$\begin{array}{c}\text { Council } \\
\text { Discusses } \\
\text { Griev. } \\
(6)\end{array}$} & \multirow{4}{*}{$\begin{array}{l}\text { Org. } \\
\text { Youth } \\
\text { Activ. } \\
\quad(7)\end{array}$} & \multirow{4}{*}{$\begin{array}{c}\% \mathrm{HH} \\
\text { Attend } \\
\text { Govt. Mtgs. } \\
(8)\end{array}$} & \multirow{4}{*}{$\begin{array}{c}\text { RD } \\
\text { Cadre in } \\
\text { Hamlet } \\
(9)\end{array}$} & \multirow{4}{*}{$\begin{array}{c}\% \mathrm{HH} \\
\text { Part. } \\
\text { RD Cadre } \\
(10)\end{array}$} & Households & \multirow{3}{*}{$\begin{array}{l}\text { Civ. Soc. } \\
\text { Provides } \\
\text { nce }\end{array}$} \\
\hline & Society & & & & & & & & & & Require & \\
\hline & LCA & Civic Org & Econ. Train. & & & & & & & & Assistance & \\
\hline & $(1)$ & $(2)$ & $(3)$ & & & & & & & & $(11)$ & $(12)$ \\
\hline Dai Viet & 0.175 & 0.262 & 0.211 & 0.077 & 0.099 & -0.011 & -0.036 & 0.104 & 0.009 & 0.174 & -0.075 & 0.165 \\
\hline & $(0.035)$ & $(0.027)$ & $(0.027)$ & $(0.028)$ & $(0.024)$ & $(0.020)$ & $(0.033)$ & $(0.028)$ & $(0.030)$ & $(0.035)$ & $(0.038)$ & $(0.042)$ \\
\hline Obs & 2,285 & 2,325 & 2,348 & 2,330 & 388 & 384 & 388 & 2,331 & 2,337 & 2,314 & 2,330 & 2,206 \\
\hline Clusters & 392 & 397 & 399 & 397 & 388 & 384 & 388 & 397 & 397 & 396 & 397 & 388 \\
\hline Mean & 0.76 & 0.37 & 0.22 & 0.62 & 0.83 & 0.93 & 0.78 & 0.37 & 0.76 & 0.52 & 0.61 & 0.24 \\
\hline
\end{tabular}

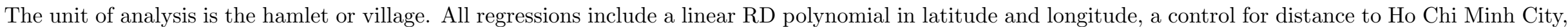
and boundary segment fixed effects. Robust standard errors, clustered at the village level, are reported in parentheses.

Table 7: Local Administration

\begin{tabular}{|c|c|c|c|c|c|c|c|c|c|c|c|}
\hline \multicolumn{12}{|c|}{ Dependent variable is: } \\
\hline & Local & Govt. & Vilg. & Vilg. & Hamlet & Police & Chief & Govt. & Lack & Tech. & Prov. Land \\
\hline & Admin. & Syst. & Comm. & Chief & Chief & Regularly & Controls & Provides & Prov. Tech. & Pers. & Affairs \\
\hline & LCA & Taxes & Filled & & Present & & RD Cadre & Assist. & Assist. & Visit & Visit \\
\hline & (1) & $(2)$ & $(3)$ & (4) & $(5)$ & (6) & $(7)$ & $(8)$ & $(9)$ & $(10)$ & $(11)$ \\
\hline \multirow[t]{2}{*}{ Dai Viet } & 0.039 & 0.060 & 0.062 & 0.057 & 0.036 & 0.166 & 0.081 & 0.141 & 0.012 & 0.003 & 0.001 \\
\hline & $(0.017)$ & $(0.035)$ & $(0.028)$ & $(0.033)$ & $(0.024)$ & $(0.048)$ & $(0.020)$ & $(0.048)$ & $(0.030)$ & $(0.048)$ & $(0.055)$ \\
\hline Obs & 2,285 & 388 & 388 & 388 & 2,317 & 2,339 & 382 & 2,221 & 387 & 386 & 308 \\
\hline Clusters & 392 & 388 & 388 & 388 & 396 & 397 & 382 & 390 & 387 & 386 & 308 \\
\hline Mean & 0.98 & 0.84 & 0.87 & 0.93 & 0.92 & 0.56 & 0.88 & 0.30 & 0.18 & 0.53 & 0.72 \\
\hline
\end{tabular}

The unit of analysis is the hamlet or village. All regressions include a linear RD polynomial in latitude and longitude, a control for distance to Ho Chi Minh City, and boundary segment fixed effects. Robust standard errors, clustered at the village level, are reported in parentheses. 
Table 8: Public Goods

\begin{tabular}{|c|c|c|c|c|c|c|c|c|c|c|c|c|}
\hline & \multicolumn{12}{|c|}{ Dependent variable is: } \\
\hline & \multirow{3}{*}{$\begin{array}{c}\text { Health } \\
\text { Care } \\
\text { LCA } \\
(1)\end{array}$} & \multirow{3}{*}{$\begin{array}{c}\text { Govt. } \\
\text { Med. Serv. } \\
\text { Avail. } \\
(2)\end{array}$} & \multirow{3}{*}{$\begin{array}{c}\text { Health } \\
\text { Wkrs. Visit } \\
\text { Reg. } \\
(3)\end{array}$} & \multirow{3}{*}{\multicolumn{2}{|c|}{$\begin{array}{c}\text { Health Mat. } \\
\text { Clinic } \\
\text { in Village }\end{array}$}} & \multirow{3}{*}{$\begin{array}{l}\text { Educ. } \\
\text { LCA } \\
(6)\end{array}$} & \multirow{2}{*}{\multicolumn{2}{|c|}{$\begin{array}{c}\text { Primary } \\
\text { School }\end{array}$}} & \multirow{2}{*}{\multicolumn{2}{|c|}{$\begin{array}{c}\text { Secondary } \\
\text { School }\end{array}$}} & \multirow{3}{*}{$\begin{array}{l}\text { Attend. } \\
\text { Restr. } \\
\text { by Sec. } \\
(11)\end{array}$} & \multirow{3}{*}{$\begin{array}{c}\text { Law } \\
\text { Enforced } \\
\text { Day/Night } \\
(12)\end{array}$} \\
\hline & & & & & & & & & & & & \\
\hline & & & & & & & $\begin{array}{c}\text { Access. } \\
(7)\end{array}$ & $\begin{array}{c}\text { Completion } \\
(8)\end{array}$ & $\begin{array}{c}\text { In Vilg. } \\
(9)\end{array}$ & $\begin{array}{l}\text { Attend. } \\
\text { (10) }\end{array}$ & & \\
\hline \multirow[t]{2}{*}{ Dai Viet } & 0.140 & 0.204 & 0.339 & 0.140 & 0.022 & 0.052 & 0.057 & 0.089 & 0.085 & 0.030 & -0.018 & 0.215 \\
\hline & $(0.043)$ & $(0.037)$ & $(0.042)$ & $(0.050)$ & $(0.067)$ & $(0.044)$ & $(0.022)$ & $(0.031)$ & $(0.059)$ & $(0.013)$ & $(0.013)$ & $(0.046)$ \\
\hline Obs & 2,285 & 2,339 & 2,336 & 388 & 388 & 2,285 & 2,336 & 388 & 388 & 388 & 2,333 & 2,333 \\
\hline Clusters & 392 & 397 & 397 & 388 & 388 & 392 & 396 & 388 & 388 & 388 & 396 & 397 \\
\hline Mean & 0.86 & 0.39 & 0.47 & 0.79 & 0.61 & 0.82 & 0.90 & 0.61 & 0.35 & 0.18 & 0.02 & 0.79 \\
\hline
\end{tabular}

The unit of analysis is the hamlet or village. All regressions include a linear RD polynomial in latitude and longitude, a control for distance to Ho Chi Minh City, and boundary segment fixed effects. Robust standard errors, clustered at the village level, are reported in parentheses.

Table 9: Public Opinion

\begin{tabular}{|c|c|c|c|c|c|c|c|c|c|}
\hline & \multicolumn{9}{|c|}{ Dependent variable is: } \\
\hline & Gvt. & Local & Knows Vilg & LTT & \multicolumn{2}{|c|}{ Natl. Gvt. } & People & Active in & People \\
\hline & Responsive & Officials & Admin. & Fairly & Performs & Man. Econ. & Respons. & Interest & Decide \\
\hline & Citizens & Successful & Struct. Well & Administ. & Poorly & Poorly & Comm. Life & Group & SDP \\
\hline & (1) & $(2)$ & $(3)$ & $(4)$ & $(5)$ & $(6)$ & $(7)$ & $(8)$ & $(9)$ \\
\hline \multirow[t]{2}{*}{ Dai Viet } & 0.098 & 0.202 & 0.119 & 0.350 & 0.110 & 0.087 & 0.271 & 0.395 & 0.222 \\
\hline & $(0.044)$ & $(0.075)$ & $(0.044)$ & $(0.075)$ & $(0.040)$ & $(0.040)$ & $(0.075)$ & $(0.146)$ & $(0.052)$ \\
\hline Obs & 2,779 & 3,487 & 1,457 & 999 & 2,811 & 5,778 & 879 & 243 & 353 \\
\hline Clusters & 190 & 183 & 89 & 101 & 182 & 215 & 106 & 35 & 53 \\
\hline Mean & 0.37 & 0.52 & 0.22 & 0.57 & 0.19 & 0.31 & 0.18 & 0.18 & 0.23 \\
\hline
\end{tabular}

The unit of analysis is the individual. All regressions include a linear RD polynomial in latitude and longitude, a control for distance to Ho Chi Minh City, and boundary segment fixed effects. Robust standard errors, clustered at the village level, are reported in parentheses. 
Table 10: Current Outcomes

\begin{tabular}{lcccccc}
\hline & \multicolumn{6}{c}{ Dependent variable is: } \\
\hline & $\begin{array}{c}\text { Contributed } \\
\text { to Charity } \\
\text { Fund }\end{array}$ & $\begin{array}{c}\text { Share } \\
\text { Communes }\end{array}$ & \multicolumn{5}{c}{ Years Schooling } \\
& Lower Sec. & $>25$ & $25-40$ & $40-60$ & $>60$ \\
& $(1)$ & $(2)$ & $(3)$ & $(4)$ & $(5)$ & $(6)$ \\
\hline Dai Viet & 0.122 & 0.292 & 0.950 & 0.899 & 0.989 & 0.982 \\
& $(0.035)$ & $(0.069)$ & $(0.195)$ & $(0.192)$ & $(0.237)$ & $(0.232)$ \\
Obs & 5,889 & 124 & 42,189 & 17,985 & 17,273 & 6,931 \\
Clusters & 450 & 124 & 453 & 452 & 453 & 442 \\
Mean & 0.70 & 0.78 & 7.45 & 8.41 & 7.67 & 4.38 \\
\hline
\end{tabular}

The unit of analysis is the household, district, or individual. All columns include a linear RD polynomial in latitude and longitude, a control for distance to Ho Chi Minh City, and boundary segment fixed effects. Columns (1) and (3) through (6) include year fixed effects. Robust standard errors, clustered at the village level, are reported in parentheses.

Table 11: Additional Mechanisms - The Vietnam War

\begin{tabular}{|c|c|c|c|c|c|c|c|c|c|c|c|c|}
\hline & \multicolumn{12}{|c|}{ Dependent variable is: } \\
\hline & \multirow{4}{*}{$\begin{array}{c}\text { Security } \\
\text { LCA } \\
(1)\end{array}$} & \multirow{4}{*}{$\begin{array}{c}\mathrm{VC} \\
\text { Forces } \\
\text { Present } \\
(2)\end{array}$} & \multirow{4}{*}{$\begin{array}{c}\text { VC } \\
\text { Base } \\
\text { Nearby } \\
(3)\end{array}$} & \multirow{4}{*}{$\begin{array}{c}\text { Vilg. } \\
\text { Guerr. } \\
\text { Squad } \\
(4)\end{array}$} & \multirow{4}{*}{$\begin{array}{c}\text { VC } \\
\text { Main } \\
\text { Squad } \\
(5)\end{array}$} & \multirow{4}{*}{$\begin{array}{c}\text { VC } \\
\text { Infra } \\
\text { Activity } \\
(6)\end{array}$} & \multirow{4}{*}{$\begin{array}{c}\mathrm{VC} \\
\text { Taxation } \\
(7)\end{array}$} & \multirow{4}{*}{$\begin{array}{c}\text { Friendly } \\
\text { Forces } \\
\text { Nearby } \\
(8)\end{array}$} & \multirow{4}{*}{$\begin{array}{c}\text { Air/Art. } \\
\text { Strke } \\
\text { Nearby } \\
(9)\end{array}$} & U..S. & SVN & Territ. \\
\hline & & & & & & & & & & \multirow{2}{*}{\multicolumn{2}{|c|}{$\begin{array}{l}\text { Initiated } \\
\text { Attack }\end{array}$}} & \multirow{3}{*}{$\begin{array}{c}\text { Forces } \\
\text { Present } \\
\quad(12)\end{array}$} \\
\hline & & & & & & & & & & & & \\
\hline & & & & & & & & & & $(10)$ & $(11)$ & \\
\hline \multirow[t]{2}{*}{ Dai Viet } & 0.003 & -0.049 & -0.035 & 0.065 & -0.102 & 0.023 & -0.014 & -0.024 & -0.040 & -0.000 & -0.109 & -0.015 \\
\hline & $(0.043)$ & $(0.035)$ & $(0.052)$ & $(0.038)$ & $(0.039)$ & $(0.032)$ & $(0.016)$ & $(0.037)$ & $(0.031)$ & $(0.001)$ & $(0.024)$ & $(0.026)$ \\
\hline Obs & 2,285 & 2,335 & 390 & 390 & 390 & 2,339 & 389 & 389 & 388 & 2,358 & 2,358 & 2,348 \\
\hline Clusters & 392 & 398 & 390 & 390 & 390 & 398 & 389 & 389 & 388 & 400 & 400 & 399 \\
\hline Mean & 0.80 & 0.15 & 0.49 & 0.20 & 0.23 & 0.09 & 0.07 & 0.49 & 0.13 & 0.00 & 0.71 & 0.24 \\
\hline
\end{tabular}

The unit of analysis is the hamlet or village. All regressions include a linear RD polynomial in latitude and longitude, a control for distance to Ho Chi Minh City, and boundary segment fixed effects. Robust standard errors, clustered at the village level, are reported in parentheses. 
Table 12: Additional Mechanisms - Land and Markets

\begin{tabular}{lcccccccc}
\hline & \multicolumn{9}{c}{ Dependent variable is: } \\
\hline & Agric. & $\begin{array}{c}\text { Agric. } \\
\text { Land } \\
\end{array}$ & $\begin{array}{c}\text { Main } \\
\text { H.H. }\end{array}$ & $\begin{array}{c}\text { Job in } \\
\text { Size }\end{array}$ & $\begin{array}{c}\text { Andustry } \\
\text { Innal }\end{array}$ & $\begin{array}{c}\text { Share } \\
\text { Perennial } \\
\text { Land Certified }\end{array}$ Residential & $\begin{array}{c}\text { H.H. } \\
\text { Interest } \\
\text { Expenses }\end{array}$ & $\begin{array}{c}\text { Employed } \\
\text { Informal } \\
\text { Sector }\end{array}$ \\
& $(1)$ & $(2)$ & $(3)$ & $(4)$ & $(5)$ & $(6)$ & $(7)$ & $(8)$ \\
\hline Dai Viet & -0.190 & -0.020 & -0.013 & -0.118 & -0.125 & -0.218 & -0.090 & -0.069 \\
& $(0.034)$ & $(0.103)$ & $(0.022)$ & $(0.041)$ & $(0.049)$ & $(0.064)$ & $(0.032)$ & $(0.021)$ \\
Obs & 16,419 & 4,518 & 20,357 & 176 & 173 & 170 & 4,553 & 20,343 \\
Clusters & 453 & 285 & 453 & 131 & 129 & 128 & 251 & 453 \\
Mean & 0.24 & 0.87 & 0.25 & 0.93 & 0.92 & 0.94 & 0.25 & 0.62 \\
\hline
\end{tabular}

The unit of analysis is the household, individual, or commune. All columns include a linear RD polynomial in latitude and longitude, a control for distance to Ho Chi Minh City, year fixed effects, and boundary segment fixed effects. Robust standard errors, clustered at the village level, are reported in parentheses. 